Review

\title{
Emerging Immunotherapy for Acute Myeloid Leukemia
}

\author{
Rikako Tabata ${ }^{1,2,+}$, SungGi Chi ${ }^{1,+} \oplus$, Junichiro Yuda ${ }^{1}\left(\mathbb{C}\right.$ and Yosuke Minami ${ }^{1, *}$ \\ 1 Department of Hematology, National Cancer Center Hospital East, Kashiwa 277-8577, Japan; \\ tabata.rikako@kameda.jp (R.T.); schi@east.ncc.go.jp (S.C.); jyuda@east.ncc.go.jp (J.Y.) \\ 2 Department of Hematology, Kameda Medical Center, Kamogawa 296-8602, Japan \\ * Correspondence: yominami@east.ncc.go.jp; Tel.: +81-4-7133-1111; Fax: +81-7133-6502 \\ + These authors contributed equally.
}

check for updates

Citation: Tabata, R.; Chi, S.; Yuda, J.; Minami, Y. Emerging Immunotherapy for Acute Myeloid Leukemia. Int. J. Mol. Sci. 2021, 22, 1944. https:// doi.org/10.3390/ijms22041944

Academic Editor: Lih Kuo Received: 23 January 2021 Accepted: 12 February 2021 Published: 16 February 2021

Publisher's Note: MDPI stays neutral with regard to jurisdictional claims in published maps and institutional affiliations.

Copyright: (c) 2021 by the authors. Licensee MDPI, Basel, Switzerland. This article is an open access article distributed under the terms and conditions of the Creative Commons Attribution (CC BY) license (https:// creativecommons.org/licenses/by/ $4.0 /)$.

\begin{abstract}
Several immune checkpoint molecules and immune targets in leukemic cells have been investigated. Recent studies have suggested the potential clinical benefits of immuno-oncology (IO) therapy against acute myeloid leukemia (AML), especially targeting CD33, CD123, and CLL1 , as well as immune checkpoint inhibitors (e.g., anti-PD (programmed cell death)- 1 and antiCTLA4 (cytotoxic T-lymphocyte-associated protein 4) antibodies) with or without conventional chemotherapy. Early-phase clinical trials of chimeric antigen receptor (CAR)-T or natural killer (NK) cells for relapsed/refractory AML showed complete remission (CR) or marked reduction of marrow blasts in a few enrolled patients. Bi-/tri-specific antibodies (e.g., bispecific T-cell engager (BiTE) and dual-affinity retargeting (DART)) exhibited $11-67 \%$ CR rates with $13-78 \%$ risk of cytokine-releasing syndrome (CRS). Conventional chemotherapy in combination with anti-PD-1/anti-CTLA4 antibody for relapsed/refractory AML showed 10-36\% CR rates with 7-24 month-long median survival. The current advantages of IO therapy in the field of AML are summarized herein. However, although cancer vaccination should be included in the concept of IO therapy, it is not mentioned in this review because of the paucity of relevant evidence.
\end{abstract}

Keywords: acute myeloid leukemia (AML); immune check-point inhibitor (ICI); bispecific T-cell engager (BiTE); dual-affinity retargeting (DART); trispecific killer cell engager (TriKE); chimeric antigen receptor (CAR)

\section{Introduction}

Since the Food and Drug Administration (FDA) approved ipilimumab, the first-inclass anti-CTLA-4 (cytotoxic T-lymphocyte-associated protein 4) antibody, for melanoma in March 2011 [1], immune checkpoint inhibitors (ICIs) such as nivolumab, pembrolizumab, atezolizumab, and durvalumab have been eagerly developed and are now practically available for a variety of malignant tumors. For the majority of solid tumors, immuno-oncology (IO) therapy has been involved in mainstream cancer treatment along with molecular targeted therapy, conventional chemotherapy, and radiation therapy. In the field of hematologic malignancies, the first bispecific T-cell engager (BiTE) blinatumomab, a CD19and CD3-targeted bispecific antibody, achieved complete remission with 6.7 month-long duration in $32 \%$ of the patients with B-cell lymphoblastic leukemia (B-ALL) in a clinical study [2] and has shown efficacy in non-Hodgkin lymphomas (NHLs) [3,4]. Currently, chimeric antigen receptor (CAR)-T therapy also accounts for an essential part of IO therapy against hematologic malignancies. The first-in-class CD19-targeted CAR-T tisagenlecleucel (also known as tisa-cel) was approved by the FDA for relapsed/refractory B-ALL in August 2017 and diffuse large B cell lymphoma (DLBCL) in May 2018, with overall remission rates of $83 \%$ and $52 \%$, respectively [5,6]. A multicenter phase $1 / 2$ study ZUMA- 1 also showed somwhat better response rates ( $82 \%$ ) of another CD19-targeted CAR-T axicabtagene ciloleucel (also known as axi-cel) for refractory DLBCL [7]. Traditional monoclonal antibodies (e.g., rituximab, alemtuzumab, obinutuzumab, and mogamulizumab) and antibody-drug 
conjugates (ADCs) (e.g., gemtuzumab ozogamicin (GO) and brentuximab vedotin) are also used in IO therapy. Novel agents of CAR-Ts, ADCs, and bispecific antibodies are currently under development.

Intensive chemotherapy (e.g., anthracyclines and cytarabine) with or without hematopoietic stem cell transplantation (SCT) has been the mainstay of the curative treatment of acute myeloid leukemia (AML), presenting a dismal prognosis for relapsed/refractory or intolerable cases which mostly require palliative care. For CD33-positive AML, GO showed an overall response rate of $63 \%$ in relapsed/refractory cases [8], along with survival benefit in newly diagnosed cases when combined with conventional chemotherapy [9]. Due to the paucity of favorable immune targets in leukemic cells, IO approaches for AML have been limited. However, as immune inhibitory molecules and cancer-related antigens on leukemic cells have been discovered, novel IO drugs have been recently developed in the field of AML and are expected to become another treatment option. Recent representative advantages in terms of IO therapy are summarized in this review.

\section{Molecules Involved in IO Therapy}

\subsection{Immune Checkpoint Molecules}

2.1.1. Programmed Cell Death 1 (PD-1), Programmed Cell Death-Ligand 1 (PD-L1), and Cytotoxic T-Lymphocyte-Associated Protein 4 (CTLA-4)

The inhibitory surface receptor programmed cell death 1 (PD-1) (UniProtKB-Q15116) on activated T cells is encoded by the PDCD1 gene on chromosome 2q37.3. Along with its ligands PD-L1 and PD-L2, also known as CD274 and CD273, PD-1 plays an important role in maintaining self-tolerance [10] and is often involved in immune escape in cancer by inhibiting the direct cytotoxic activity of effector CD8-positive T cells on tumor cells [11]. CTLA- 4 on activated T cells, which is encoded by the CTLA4 gene on chromosome 2 q33.2, also has a crucial role in attenuating $\mathrm{T}$ cell activation in peripheral lymph nodes by preventing CD28 on T cells to bind its co-stimulatory counterparts B7 family ligands (CD80 and CD86) on antigen-presenting cells [12,13]. An in vivo study of murine myelogenous leukemia suggested that blockade of B7-1 (CD80) and not B7-2 (CD86) by CTLA-4 contributed to the attenuation of anti-leukemic immunity [14].

An observational study at the MD Anderson Cancer Center analyzed bone marrow and peripheral blood specimens from 124 patients with myelodysplastic syndrome (MDS), chronic myelo-monocytic leukemia (CMML), and AML who received hypomethylating agents (HMAs) and reported that PD-1 and PD-L1 expression on CD34-positive cells were found in $7 \%$ and $20 \%$ of the patients, respectively [15]. In $57 \%$ of previously untreated patients, PD-L1 and PD-L2 expression on peripheral blood mononuclear cells (PBMNCs) increased more than twice during the first cycle of HMA. These patients had a shorter median survival than those who did not (4.7-6.6 vs. 11.7-12.5 months), suggesting the negative impact of PD-L1 and PD-L2 on the anti-tumor effect of HMAs. Upregulation of CTLA-4 on PBMNCs was also observed in $8 \%$ of the patients. Another study suggested that PD-L1 expression was higher in relapsed cases and associated with poor prognosis [16]. Epigenetic analysis of 197 AML specimens revealed that the less methylated promoters of PD-L1 and PD-L2 gene in leukemic cells were an independent negative prognostic factor [17]. Analysis of bone marrow samples from nine refractory/relapsed AML patients showed a higher proportion (22\%) of CD8-positive T cells co-expressing PD-1 and larger T-cell clonal expansion measured by T-cell receptor rearrangement compared with healthy donor samples [18]. PD-1 and OX40 on bone marrow T cells were more frequently found in relapsed AML samples than in newly diagnosed ones [19]. A report from China showed that PD-1 expression was seen in 33.8\% of the peripheral CD3-positive lymphocytes in patients with previously untreated de novo AML and was correlated with the increased expression of exhaustion markers such as CD244 and CD57 [20]. However, other experiments suggested that PD-1 expression does not result in functional impairment of T cells, but rather correlates with a shift to memory cells [21]. Twenty-three samples from patients with AML were compared with those of 30 healthy controls. Although relatively high 
( $>30 \%$ ) PD-1 expression on CD8-positive T cells was observed in 3 of 23 (13\%) AML samples, the median percentages did not differ significantly compared with healthy controls (median 15.6\%). Other immune inhibitory markers, CD244, CD160, and TIM-3, were also not significantly expressed. Instead, PD-1 was upregulated in peripheral blood specimens of patients with AML who relapsed after either intensive chemotherapy or allogeneic stem cell transplantation (allo-SCT) compared with those of the same patients at the time of diagnosis.

\subsubsection{T-Cell Immunoglobulin and Mucin-Domain Containing-3 (TIM-3)}

The cell surface receptor T-cell immunoglobulin and mucin-domain containing-3 (TIM-3), also known as hepatitis A virus cellular receptor 2 (HAVcr-2), is encoded by the HAVCR2 gene on chromosome 5q33.3. TIM-3 is normally expressed on T-helper type 1 (Th1) lymphocytes, regulatory T cells (Treg), and natural killer (NK) cells. TIM-3 regulates macrophage activation [22], promotes immunological tolerance by inhibiting Th1-mediated responses [23], attenuates T-cell receptor (TCR)-induced signaling in CD8positive T cells [24], and inhibits Th17 responses when expressed on Tregs [25]. The first identified ligand for TIM-3 is galectin-9 [26], which is also a ligand for P4HB and CD44 [27]. It contributes to the stabilization/empowerment of induced Tregs [27], helps mesenchymal stromal cells in suppressing T cells [28], and inhibits NK cell activity [29]. TIM-3 is also able to bind phosphatidylserine (PtdSer) [30], HMGB1 [31], and CEACAM1 [32] to prevent the activation of the immune response.

TIM-3 was found in approximately $6 \%$ of the bone marrow T cells in newly diagnosed AML patients, and the proportion was larger (11.5-18.5\%) in FLT3-ITD mutated cases [33]. Simultaneous expression of PD- 1 and TIM- 3 on peripheral T cells was associated with AML relapse after allo-SCT [34]. An in vitro experiment using murine AML cells demonstrated that co-expression of TIM-3 and PD-1 on CD8-positive T cells was enhanced during disease progression and inhibition of either molecule alone did not attenuate tumor activity [35]. TIM-3 is also expressed on NK cells [36], while galectin-9 is found in AML blasts [37]. TIM-3/galectin-9 interaction leads to the production of IFN-gamma by NK cells, resulting in indoleamine 2,3-dioxygenase 1 (IDO1) expression in AML cells [38]. IDO1-positive AML cells gained the ability to negatively regulate NK cell degranulation, which can be responsible for the immune escape of leukemic cells. Another in vitro study suggested that AML cells protect themselves by producing soluble TIM-3 to form a TIM-3-galectin-9 complex that attenuates NK cell-mediated cytotoxicity [39].

TIM-3 inhibitors are currently under early phase evaluation as monotherapies or in combination with PD-1/PD-L1 inhibitors for patients with advanced tumors. Preclinically, CAR-T therapy bispecific for CD13 and TIM-3 has been efficiently screened by a nanobodybased technology and shows eradication of leukemic cells in mouse models [40].

\subsubsection{Lymphocyte Activation Gene-3 Protein (LAG-3)}

The inhibitory receptor lymphocyte activation gene-3 protein (LAG-3), also known as CD223, is encoded by the LAG-3 gene on chromosome 12p13.31. LAG-3 is normally expressed on activated T cells, NK cells, and plasmacytoid dendritic cells (DCs) [41,42]. Notably, CD4-positive/CD25-high/Foxp3-positive/LAG-3-positive T cells were preferentially expanded in patients with cancer [43]. LAG-3 structurally resembles CD4 and binds to major histocompatibility complex (MHC) class II on CD4-positive T cells, resulting in the downregulation of their antigen-mediated activity [44-46]. LAG-3 and PD-1 synergistically prevent autoimmunity and promote immune escape in cancer [47,48]. An in vitro experiment reported that $\mathrm{T}$ cells co-expressing LAG-3 and PD- 1 were frequently seen in bone marrow samples from patients with relapsed AML [49]. An in vivo study of murine chronic lymphocytic leukemia showed that dual inhibition of PD-1 and LAG-3 successfully decreased tumor load [50]. Anti-PD-1 antibodies with or without anti-LAG-3 antibody are now being evaluated in early phase trials for solid and hematologic malignancies [51,52], although these results have not been reported yet. 


\subsubsection{Leukocyte Surface Antigen CD47}

CD47, encoded by the CD47 gene on chromosome 3q13.12, is a transmembrane glycoprotein and a ligand for signal-regulatory proteins (SIRPs). SIRP $\alpha$ is expressed on macrophages, DCs, myeloid cells, neurons, and astrocytes. In terms of macrophages and DCs, SIRP $\alpha$-CD47 binding inhibits their phagocytic function through the cytoplasmic domain of SIRP $\alpha$ called immunoreceptor tyrosine-based inhibition motifs (ITIMs) by recruiting SH2 domain-containing protein tyrosine phosphatase (SHP)-1 and SHP-2 [53,54]. In other words, CD47-expressing cells are prevented from being engulfed, which have been recognized as the "don't eat me" signal. Another member of the family, SIRP $\beta 2$ is expressed on T cells and NK cells. Unlike SIRP $\alpha$, binding of SIRP $\beta 2$ on T cells to CD47 on antigen-presenting cells results in antigen-specific $\mathrm{T}$ cell proliferation and $\mathrm{T}$ cell activation, although its affinity for CD47 is weaker than that of SIRP $\alpha$ [55]. Although CD47 is broadly expressed in a variety of normal tissues, it is upregulated in human leukemic cells as well as circulating hematopoietic stem cells (HSCs) [56], and are also related to poor prognoses [57]. A preclinical study in which human tumor cells were co-cultured with $\operatorname{SIRP} \alpha \mathrm{Fc}$ (TTI-621) that binds to CD47 demonstrated the anti-tumor effect of CD47-blockade on various solid and hematologic malignancies [58]. A phase Ib study of anti-CD47 monoclonal (Hu5F9-G4) antibody in combination with rituximab for relapsed or refractory B-cell non-Hodgkin lymphomas showed good tolerability and CR rates of 36\% [59], although drug-related anemia occurred as an adverse event [60].

\subsubsection{Other Checkpoint Molecules}

Similar to the CD47 receptor SIRP $\alpha$, the B- and T-lymphocyte attenuator (BTLA; also known as CD272) and CD200R (also called OX-2 receptor) have cytoplasmic ITIMs which induce inhibitory signaling in immune effector cells [61-63]. CD200 overexpression in AML/MDS cells was associated with higher relapse rates and poor prognoses [64]. Blockade of the BTLA and CD200R/CD200 axis has demonstrated enhanced anti-tumor immunity in preclinical settings $[65,66]$. Nevertheless, no clinical trials have been conducted to date. B7-homolog 3 (B7-H3; also known as CD276) is one of the B7 family molecules normally expressed on activated APCs and negatively regulates T-cell activation [67]. B7-H3 has been discovered in a variety of solid and hematologic malignancies, and is expected to be a pan-cancer target for IO therapy [68]. A preclinical experiment in which B7-H3-targeted CAR-T cells were co-cultured with 10 samples from AML patients in vitro and administered to human AML-transplanted mice showed significant cytotoxicity in four (40\%) patient-derived samples and prolonged survival of the xenograft mice [69]. Representative immune checkpoint molecules are summarized in Figure 1. 


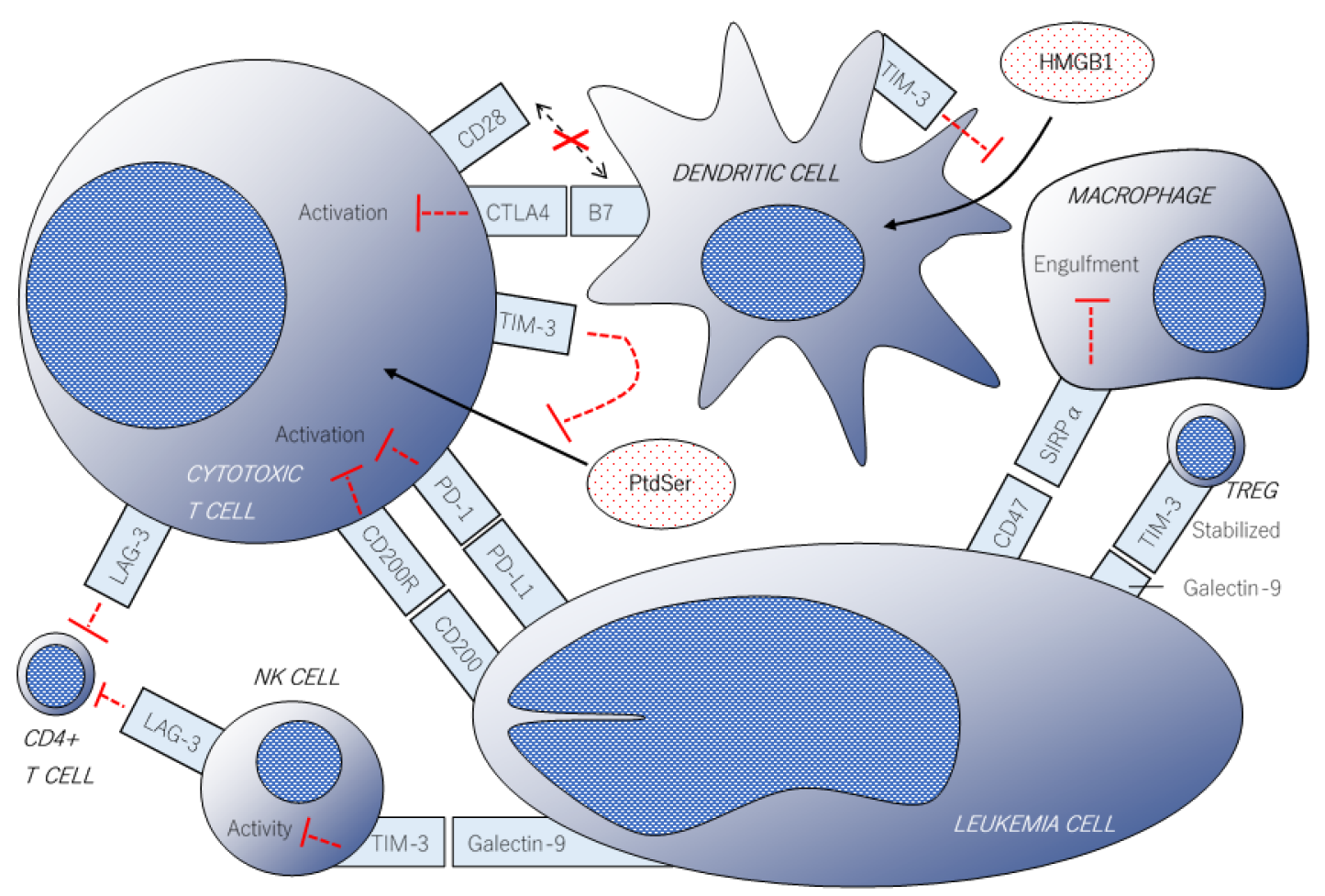

Figure 1. The scheme of immune checkpoint molecules associated with anti-leukemic immunity. Direct cytotoxicity in leukemic cells is attenuated by the binding of programmed cell death-1 (PD-1) on T cells and programmed cell death-ligand 1 (PD-L1) on cancer cells. T-cell activation via B7 family molecules on dendritic cells is canceled by cytotoxic T-lymphocyteassociated protein 4 (CTLA-4). Phagocytic activity of macrophages is dampened by the "don't eat me" signals of CD47 on leukemic cells. Lymphocyte activation gene-3 protein (LAG-3) expressed on T cells or natural killer cells inhibit the activity of CD4-positive T cells. T-cell immunoglobulin and mucin-domain containing-3 (TIM-3) has multiple inhibitory mechanisms such as attenuation of natural killer (NK) cell activity/stabilization of regulatory T cells by binding to galectin-9 and neutralizing the pro-inflammatory effect of HMGB1 and phosphatidylserine (PtdSer).

\subsection{Potential Immune Targets on Leukemic Cells}

\subsubsection{Interleukin-3 Receptor Subunit Alpha (IL-3RA) or CD123}

Interleukin-3 receptor subunit alpha (IL-3RA), also known as CD123, contains the alpha-subunit of the receptor for IL-3 and is encoded by the IL3RA gene on the X chromosome. Studies have indicated that IL-3RA is overexpressed in AML cells and other hematologic malignancies but is scant in normal hematopoietic stem cells [70-72]. Ehninger et al. reported that $77.9 \%(232 / 298)$ of AML patients were positive for CD123, whereas almost none of the healthy donors were [72]. The presence of CD123 on leukemic stem cells is known to be related to the risk of treatment failure [73]. A study analyzing patient specimens showed that co-expression of CD123, CD25, and CD99 in CD34-positive leukemic cells was frequently observed in AML with FLT3-ITD mutations [74]. Yan and his colleagues demonstrated that the expression of CD123 and CD47 in leukemic stem cells increased in chemo-resistant cell lines compared with chemo-naive ones [75]. Interestingly, romidepsin, an HDAC inhibitor, re-sensitized these resistant cells in vitro. A dual-affinity retargeting (DART) molecule targeting both CD123 and CD3, called MGD006, induced dose-dependent killing of AML cell lines in vitro and in vivo [76]. A preclinical study using AML-transplanted mice showed selective anti-tumor effects of CD123-directed CAR-T on leukemic cells [77]. Similarly, engineered T cells that secrete bispecific CD123/CD3 antibody exhibited anti-leukemic effects in a xenograft mouse model [78]. Monoclonal antibodies and ADCs directing CD123 have also shown efficacy in preclinical studies [79-81]. 


\subsubsection{Myeloid Cell Surface Antigen CD33}

CD33 is a sialic-acid-binding immunoglobulin-like lectin expressed in monocytic/myeloid lineage cells and is encoded by the CD33 gene on chromosome 19q13.41. CD33 is expressed on myeloid cell lines from the progenitor to well-differentiated cells, including neutrophils, monocytes, and tissue-resident macrophages [82]. CD33 shows positive immunostaining in at least $80-90 \%$ of patients with AML, thereby indicating its presence. While CD33 expression levels largely differ between patients, its high expression can be seen in AML with NPM1 mutation [83]. GO, a CD33-targeted ADC, has shown clinical efficacy and has been administered to AML patients in practice (mentioned in later sections). Some studies have suggested that the expression levels of CD33 may be positively related to the anti-leukemic effect of GO treatment [84-86]. The first-in-ever CD33/CD3-targeted BiTE, called AMG330, prolonged the survival of human AML-transplanted immunodeficient mice [87] and has been tested in early phase trials (mentioned in a later chapter). A novel bifunctional checkpoint inhibitory T-cell engager (CiTE), a bispecific protein for $\mathrm{CD} 3$ and CD33 conjugated with the extracellular domain of PD-1, has been recently developed and was found to improve AML in a murine xenograft model [88].

\subsubsection{C-Type Lectin-Like Molecule-1 (CLL-1)}

C-type lectin domain family 12 member A (CLEC12A; UniProtKB-Q5QGZ9), also known as c-type lectin-like molecule-1 (CLL-1), is an ITIM-containing inhibitory transmembrane glycoprotein expressed on more than $80 \%$ of AML blasts as well as leukemic stem cells. The protein is encoded by the CLEC12A gene on chromosome 12p13.31. Although the function of CLL-1 is not fully understood, its involvement in homeostasis in certain inflammatory situations, such as monosodium urate-induced reaction and collagen antibody-induced arthritis has been suggested $[89,90]$. A previous study suggested that CLL-1 is selectively present on LSCs but absent on normal HSCs, indicating this as an ideal candidate for immune targets [91]. Hutten et al. showed that CLL-1 is also expressed on myeloid and plasmacytoid DCs, enhancing delivery of tumor antigens into DCs, resulting in efficient antigen presentation on CD8-positive T cells, which was not attenuated by CLL1-targeted antibodies [92]. Two xenograft models in which patient-derived AML cells were transplanted to cynomolgus monkeys and mice, respectively, showed that CLL-1-targeted ADCs exhibited almost complete depletion of leukemic cells and tumor growth inhibition, respectively $[93,94]$. Other preclinical data have shown significant anti-leukemic potentials of monoclonal/bispecific antibodies and CAR-Ts targeting CLL-1 [95-104]. A trispecific killer cell engager (TriKE) targeting CLL-1 on leukemic cells and CD16/IL15 on NK cells increased NK cell proliferation and degranulation in leukemic cells, resulting in death in approximately $15 \%$ of the AML cells in vitro, which was comparable to that of CD33-targeted TriKE [105].

\subsubsection{Other Candidates of Immune Targets}

A proto-oncogene protein c-KIT, also known as CD117, is a type III receptor tyrosine kinase expressed in 80-90\% of AML blasts and is related to adverse clinical outcome [106]. A second-generation CAR-T targeting c-Kit demonstrated elimination of more than $90 \%$ of CD117-positive AML cells in vitro and almost complete depletion ( $>98 \%)$ of CD117positive marrow cells in xenograft mice [107]. Like c-Kit, FMS-like tyrosine kinase 3 (FLT3) is a type III receptor tyrosine kinase. FLT3 plays an important role in maintaining the survival of normal HSCs [108] and is also expressed in the vast majority of AML cells along with its recurrent mutations (e.g., internal tandem duplication (ITD) and tyrosine kinase domain mutation (TKD)) [109]. While potent FLT3 inhibitors (e.g., gilteritinib [110], midostaurin [111], and quizartinib [112]) are now available in practice, FLT3-directed novel IO approaches have been investigated to overcome resistance to the inhibitors. A preclinical study of an AML-xenograft mouse model showed that cytokine production and proliferation of FLT3-targeted CAR-T cells were strongly increased by FLT3 upregulation (4- to 13-fold) in leukemic cells after exposure to FLT3 inhibitors, which resulted in a 100\% 
response rate when combined with FLT3-targeted CAR-T and FLT3 inhibitors [113]. In addition, targets of IO therapy do not have to be single. The adapter CAR-T (aCAR-T) is a new concept in which antigen recognition of CAR-T cells is split into multiple agents (e.g., CD32, CD33, CD38, CD123, CD135, CD305, and CLL1 for AML) by linker-label-epitopes (LLEs) that allows qualitative regulation of CAR-T function (for example, recognition of four or more antigens to activate and three or less not to do). Preclinical studies of aCAR-T are ongoing, and the results are awaited [114]. Potential IO targets of AML are schematically displayed in Figure 2.

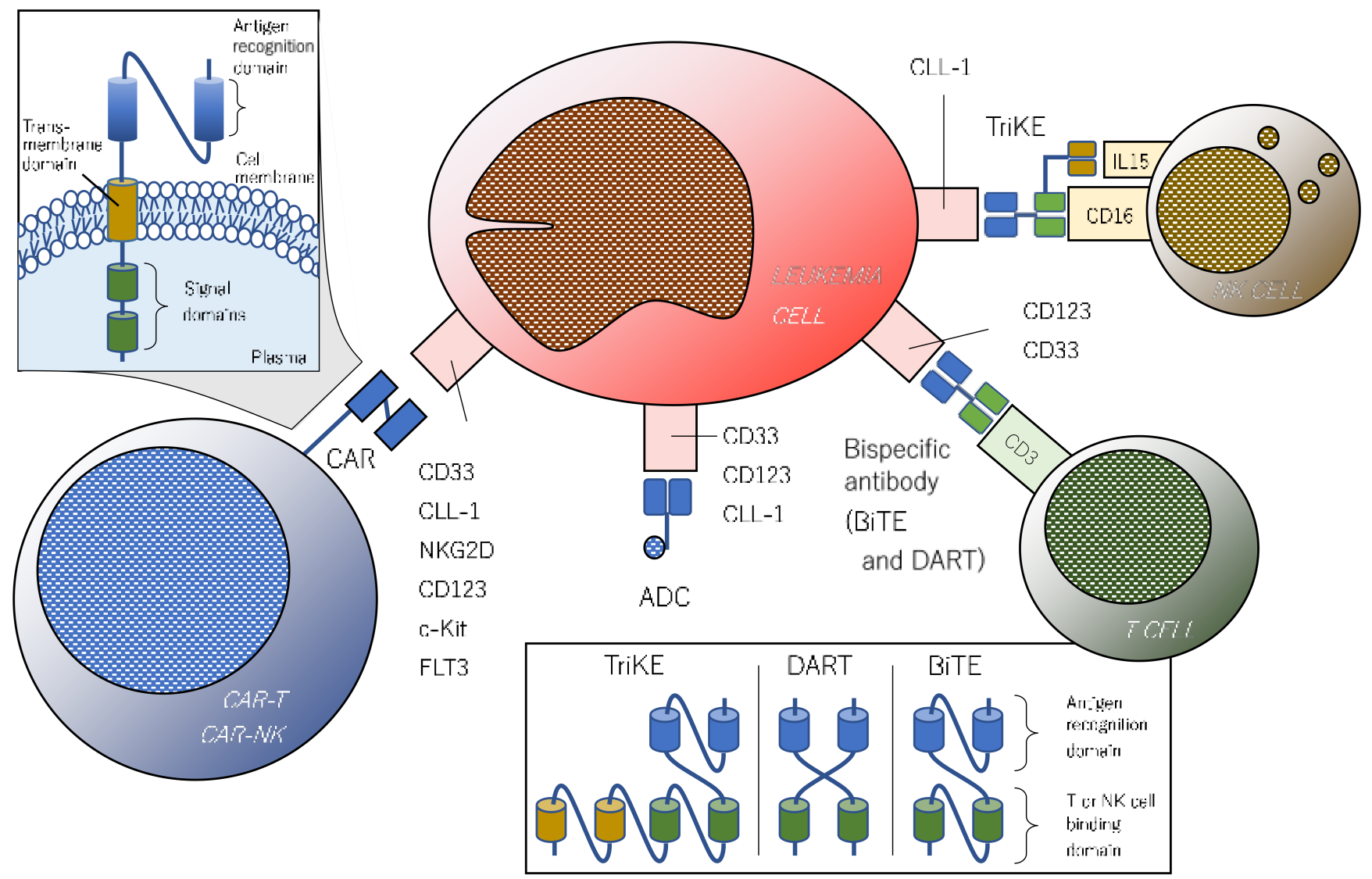

Figure 2. Potential immune targets being investigated in preclinical and early-phase trials. CAR consists of an antigenrecognizing extracellular domain and an intracellular signal domain(s). CAR-T or natural killer-targeting CD33, CLL-1, and pan-cancer antigen NKG2D have been evaluated in phase I trials. While bispecific T-cell engager (BiTE) and trispecific killer cell engager (TriKE) are composed of a single-chain variable fragment (scFv), dual-affinity retargeting (DART) is composed of two cross-linked variable fragments. Bispecific antibodies (BiTEs and DARTs) targeting CD33 and CD123 have been tested in early-phase trials. Gemtuzumab ozogamicin (GO), a CD33-directed antibody-drug conjugate, has already been used in clinical practice.

\section{Novel IO Therapy in Clinical Trials}

\subsection{Immune Checkpoint Inhibitors}

\subsubsection{Anti-PD-1/CTLA-4 Antibody}

Published trials of ICIs are listed in Table 1 . In a phase $\mathrm{Ib} / \mathrm{II}$ study that recruited 51 patients with AML that failed prior therapy, the combination of nivolumab, an anti-PD-1 antibody, and azacitidine demonstrated $18 \%$ CR and 15\% hematologic improvement [115]. The median overall survival was 9.3 months, which was favorable to historical data in which patients were treated with azacitidine alone as a salvage therapy. The author also reported a phase II study in which a combination of azacitidine, nivolumab, and ipilimumab (an anti-CTLA-4 antibody) brought about CR and CR with incomplete hematologic 
recovery (CRi) in 6 of $20(36 \%)$ patients and $58 \%$ of 1-year survival rate with severe immunerelated adverse effects (irAEs) in $26 \%$ of the patients [116]. Farhad et al. reported that the combination of nivolumab and conventional induction chemotherapy (e.g., idarubicin plus cytarabine) was feasible for patients with newly diagnosed AML [117]. CR and CRi were observed in $34(78 \%)$ of 44 patients, including 18 cases in which their minimum residual disease (MRD) was undetectable after completion of the induction therapy. The median overall survival of all patients and that of patients who underwent allogeneic hematopoietic stem cell transplantation (allo-HSCT) were 18.5 and 24 months, respectively. Another anti-PD-1 inhibitor, pembrolizumab, was also evaluated in a small pilot study [118]. Ten patients with relapsed or refractory AML received pembrolizumab along with decitabine every other cycle. CR was observed in one patient (10\%) and stable disease (SD) in four patients (40\%). The median survival time was 7 months. Ipilimumab showed a response in patients with hematologic malignancies that relapsed after allo-HSCT. In a multicenter phase I study, 28 patients with relapsed hematologic malignancies, including 12 patients with AML and 1 patient with MDS, were enrolled [119]. Among 5 patients (23\%) who achieved CR, four had AML and one had MDS. Another open-label phase I study that enrolled 29 patients with solid and hematological malignancies, including two patients with AML, who relapsed after allo-HSCT reported that tumor regression was seen in three patients $(10 \%)$ but none of them had AML [120]. The efficacy of ipilimumab was also evaluated in MDS resistant to HMAs. In a multi-center phase I study, 29 patients received ipilimumab after HMA failure [121]. One patient (3.4\%) achieved marrow CR lasting 3 months, and 7 patients (24\%) remained in SD for more than 46 weeks. 


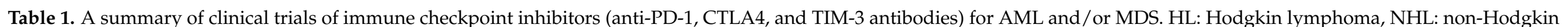

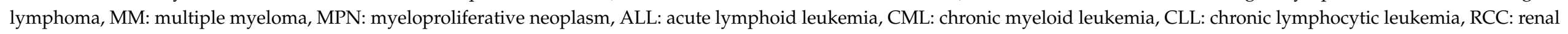

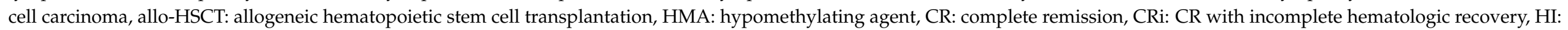
hematologic improvement, PR: partial remission, SD: stable disease, OS; overall survival.

\begin{tabular}{|c|c|c|c|c|c|c|c|c|}
\hline Author & Object(s) & Disease State & Agent(s) & Dosing & Phase & \multicolumn{2}{|c|}{ Response Rate } & Median Survival \\
\hline $\begin{array}{l}\text { Daver, et al., } \\
2016\end{array}$ & AML & $\begin{array}{l}\text { Relapsed after } \\
\text { prior therapy }\end{array}$ & $\begin{array}{l}\text { Nivolumab } \\
+ \text { Azacitidine } \\
\end{array}$ & $\begin{array}{c}3 \mathrm{mg} / \mathrm{kg} \text { on Day } 1,14 \text { (every } \\
4-5 \text { weeks) } \\
75 \mathrm{mg} / \mathrm{m}^{2} \text { on Day } 1-7 \text { (every } \\
4-5 \text { weeks) }\end{array}$ & $\mathrm{Ib} / \mathrm{II}$ & $\begin{array}{l}\text { CR/CRi } \\
\text { HI }\end{array}$ & $\begin{array}{l}18 \%(6 / 51) \\
15 \%(5 / 51)\end{array}$ & $\begin{array}{l}9.3 \mathrm{mo} . \\
{[1.8-14.3]}\end{array}$ \\
\hline $\begin{array}{l}\text { Daver, et al., } \\
2018\end{array}$ & AML & $\begin{array}{l}\text { Relapsed or } \\
\text { refractory }\end{array}$ & $\begin{array}{l}\text { Nivolumab } \\
+ \text { Azacitidin }\end{array}$ & [Cohort 1] Not Reported & II & $\begin{array}{c}\text { CR/CRi } \\
\text { HI } \\
\text { Prolonged SD }\end{array}$ & $\begin{array}{c}21 \%(15 / 70) \\
10 \%(7 / 70) \\
9 \%(6 / 70)\end{array}$ & $16.1 \mathrm{mo}$. \\
\hline $\begin{array}{l}\text { Ravandi, et al., } \\
2019\end{array}$ & $\begin{array}{c}\text { AML and } \\
\text { high-risk MDS }\end{array}$ & Newly diagnosed & $\begin{aligned} & \text { Idarubicin } \\
&+ \text { Cytarabine } \\
&+ \text { Nivolumab } \\
&\end{aligned}$ & $\begin{array}{c}12 \mathrm{mg} / \mathrm{m}^{2} \text { on Day } 1-3 \\
1.5 \mathrm{~g} / \mathrm{m}^{2} \text { on Day } 1-4 \\
3 \mathrm{mg} / \mathrm{kg} \text { (every } 2 \text { weeks) }{ }^{*} \text { started } \\
\text { on Day } 24\end{array}$ & II & $\begin{array}{c}\text { CR/CRi } \\
\text { Negative MRD }\end{array}$ & $\begin{array}{l}78 \%(34 / 44) \\
41 \%(18 / 34)\end{array}$ & $\begin{array}{c}18.5 \mathrm{mo} . \\
{[10.8-28.8]}\end{array}$ \\
\hline $\begin{array}{l}\text { Davids, et al., } \\
2016\end{array}$ & $\begin{array}{c}\text { Hematologic } \\
\text { malignancies } \\
\text { (AML, HL, NHL, } \\
\text { MDS, MM, MPN, } \\
\text { ALL) }\end{array}$ & $\begin{array}{l}\text { Relapsed after } \\
\text { allo-HSCT }\end{array}$ & Ipilimumab & $\begin{array}{c}3 \text { or } 10 \mathrm{mg} / \mathrm{kg} \text { (every } 3 \text { weeks for } \\
4 \text { doses } \\
\text { then every } 12 \text { weeks for upto } \\
6 \text { doses) } \\
\text { *All reseposive cases recieved } \\
10 \mathrm{mg} / \mathrm{kg} \text {. }\end{array}$ & $\mathrm{I} / \mathrm{Ib}$ & $\begin{array}{l}\text { CR } \\
\text { PR }\end{array}$ & $\begin{array}{l}23 \%(5 / 28) \\
9 \%(2 / 22)\end{array}$ & Not Reported \\
\hline $\begin{array}{l}\text { Bashey, et al., } \\
2009\end{array}$ & $\begin{array}{l}\text { Malignancies } \\
\text { (AML, HL, NHL, } \\
\text { MM, CML, CLL, } \\
\text { Breast cancer, } \\
\text { RCC) }\end{array}$ & $\begin{array}{l}\text { Relapsed after } \\
\text { allo-HSCT }\end{array}$ & Ipilimumab & $\begin{array}{l}0.1 \text { to } 3.0 \mathrm{mg} / \mathrm{kg} \text { (every } 60 \text { days) } \\
\text { *Dose-escalating model. }\end{array}$ & I & $\begin{array}{l}\text { CR } \\
\text { PR }\end{array}$ & $\begin{array}{l}6.9 \%(2 / 29) \\
3.4 \%(1 / 29)\end{array}$ & $24.7 \mathrm{mo}$ \\
\hline
\end{tabular}


Table 1. Cont.

\begin{tabular}{|c|c|c|c|c|c|c|c|c|}
\hline Author & Object(s) & Disease State & Agent(s) & Dosing & Phase & \multicolumn{2}{|c|}{ Response Rate } & Median Survival \\
\hline $\begin{array}{l}\text { Zeidan, et al., } \\
2018\end{array}$ & MDS & $\begin{array}{l}\text { Refractory to } \\
\text { HMAs }\end{array}$ & Ipilimumab & $\begin{array}{c}3 \text { or } 10 \mathrm{mg} / \mathrm{kg} \text { (every } 3 \text { weeks for } \\
4 \text { doses } \\
\text { then every } 12 \text { weeks for upto } \\
8 \text { doses) }\end{array}$ & I & $\begin{array}{c}\text { Marrow CR } \\
\text { Prolonged SD }\end{array}$ & $\begin{array}{l}3.4 \%(1 / 29) \\
24 \%(7 / 29)\end{array}$ & Not Reported \\
\hline $\begin{array}{l}\text { Lindblad, } \\
\text { et al., } \\
2018\end{array}$ & AML & $\begin{array}{l}\text { Relapsed or } \\
\text { refractory }\end{array}$ & $\begin{array}{l}\text { Pembrolizumab } \\
\text { + Decitabine }\end{array}$ & $\begin{array}{c}200 \mathrm{mg} / \text { body (every } 3 \text { weeks) } \\
20 \mathrm{mg} / \mathrm{m}^{2} \text { on Day 8-12, 15-19 } \\
\text { (every } 6 \text { weeks) }\end{array}$ & $\mathrm{I} / \mathrm{II}$ & $\begin{array}{l}\mathrm{CR} \\
\mathrm{SD}\end{array}$ & $\begin{array}{l}10 \%(1 / 10) \\
40 \%(4 / 10)\end{array}$ & $\begin{array}{l}7 \mathrm{mo} . \\
{[2-14]}\end{array}$ \\
\hline
\end{tabular}




\subsubsection{Anti-TIM-3 Antibody}

TIM-3 blockade can be another strategy for disarming the immune-escaping mechanisms of tumor cells. A phase Ib study testing anti-TIM-3 antibody (MBG453) in combination with decitabine for patients with high-risk MDS and AML reported that 9 of 31 (29\%) patients with AML achieved partial response or better response and eight $(25.8 \%)$ additional patients showed more than a 50\% reduction in marrow blasts [122]. Severe (Grade 3-4) irAE, liver toxicity, and arthritis occurred in 7\% of the patients; this result was comparable to those of other ICI monotherapy.

\subsection{CAR-T Therapy and Its Relatives}

CAR-T cells are engineered peripheral T cells, often of autologous origin, which have an extracellular antigen-recognition domain, commonly single-chain variable fragments derived from monoclonal antibodies, conjugated with intracellular signal domains (as shown in Figure 2). The first-generation CAR has only one signal domain (CD3 zeta chain) and the other descendants have additional co-stimulatory structures (CD28 or 4-1BB for 2nd generation and CD28 plus 4-1BB or OX40 for 3rd generation). A variety of CAR-Ts are now under development. While CD19-directed CAR-T cell therapy has been successful for B-ALL, the application of the concept for AML has been delayed due to the lack of suitable targetable surface antigens until recently. Ritchie et al. reported a phase I study of the first-in-human and proof-of-concept CAR-T therapy targeting Lewis-Y antigen in patients with relapsed/refractory AML (RR-AML) [123]. Although the clinical outcome was modest, if transient, its feasible transduction efficiency (14-38\%) and persistence of CAT-T cells within the body (up to 10 months) as well as its acceptable safety profile were displayed. Among a number of surface antigens, CD33, CD123, and CLL-1 have been eagerly investigated for CAR-T therapy. Wang et al. conducted a clinical trial in which a patient with refractory AML received CD33-directed autologous CAR-T therapy followed by marked reduction of marrow blasts lasting 9 weeks [124]. An early-phase result of CD33-targeted CAR-NK therapy (autologous NK cells with CAR) in patients with RR-AML was reported by Tang and his colleagues [125]. One of three patients who received CAR-NK therapy showed increased levels of serum interleukin (IL)- 6 and IL-10 on day 6 , followed by a decrease in the MRD level and WT1 copy-numbers, although the clinical benefit was insufficient. Co-administration of engineered DCs with CD33-directed CAR-T cells may enhance anti-leukemic activity through the production of DC-derived IL-12 [126]. A novel compound CAR-T targeting both CD33 and CLL-1 was tested in a phase I study in which a 6 year-old female with Fanconi's anemia-associated juvenile myelomonocytic leukemia carrying FLT3-ITD mutation that had been heavily treated with multiple therapies, including a FLT3 inhibitor [127]. After CAR-T infusion following lymphodepletion therapy, she achieved CR with negative MRD on day 19, which allowed her to undergo allo-SCT. Sallman et al. reported a phase I study of CAR-T therapy targeting NKG2D, which is expressed on a variety of solid and hematologic tumors, in which three of seven (42\%) patients with RR-AML achieved CR [128]. Although only a small number of patients with AML have been involved in clinical trials of CAR-T therapy, the results are promising and further investigations are expected. A summary of early phase trials is shown in Table 2. 
Table 2. A summary of early phase trials of CAR-T and CAR-NK therapy. JMML: juvenile myelomonocytic leukemia, Rel./ref.: relapsed or refractory, CR: complete remission, CRh: CR with partial hematologic recovery, CRi: CR with incomplete hematologic recovery, MRD: minimal residual disease.

\begin{tabular}{|c|c|c|c|c|c|c|}
\hline Authors & Objects & Disease State & Agents & Target(s) & Phase & Clinical Outcome \\
\hline $\begin{array}{l}\text { Rithchie, et al., } \\
2013\end{array}$ & AML & Rel./ref. & CAR-T (2nd gen.) & $\begin{array}{l}\text { Lewis-Y } \\
\text { antigen }\end{array}$ & $\mathrm{I}$ & $\begin{array}{c}\text { Transient decrease of } \\
\text { blasts in } 1 \text { of } 4 \text { patients } \\
14-38 \% \text { of } \\
\text { Transduction efficiency }\end{array}$ \\
\hline $\begin{array}{l}\text { Wang, et al., } \\
2015\end{array}$ & AML & Rel./ref. & CAR-T (2nd gen.) & CD33 & I & $\begin{array}{l}\text { Marked reduction of } \\
\text { marrow blasts } \\
\text { for } 9 \text { weeks in } 1 \text { patient }\end{array}$ \\
\hline $\begin{array}{l}\text { Sallman, et al., } \\
2018\end{array}$ & $\begin{array}{l}\text { Solid tumors } \\
\text { and } \\
\text { hematologic } \\
\text { malignancies }\end{array}$ & Rel./ref. & CAR-T & NKG2D & I & $\begin{array}{l}1 \mathrm{CRh} \text { and } 2 \mathrm{CRi} \text { of } 7 \\
\text { patients with } \mathrm{AML}\end{array}$ \\
\hline $\begin{array}{l}\text { Liu, et al., } \\
2018\end{array}$ & JMML & Rel./ref. & Compound CAR-T & $\begin{array}{l}\text { CLL-1 and } \\
\text { CD33 }\end{array}$ & I & $\begin{array}{l}\text { CR with negative MRD } \\
\text { in } 1 \text { patient }\end{array}$ \\
\hline $\begin{array}{l}\text { Tang, et al., } \\
2018\end{array}$ & AML & Rel./ref. & CAR-NK & CD33 & I & $\begin{array}{l}\text { Decrease of MRD and } \\
\text { WT- } 1 \text { in } 1 \text { of } 3 \text { patients }\end{array}$ \\
\hline
\end{tabular}

\subsection{Bispecific and Trispecific Antibodies: BiTE and DART}

Bispecific antibodies are artificially synthetized small molecules consisting of two different antigen-recognition domains derived from variable regions of monoclonal antibody. Both BiTEs and DARTs recognize CD3 and engage effector T cells with tumor cells. CD33 and CD123 are popular as leukemia-specific targets in recent investigations. BiTEs are composed of a single-chain variable fragment $(\mathrm{Fv})$, and DARTs are made by cross-linking two Fvs [129]. A CD33-targeted BiTE AMG330 was tested in a phase I study of patients with RR-AML [130]. In total, four patients out of 35 (11.4\%) participants, including those who received a low dose of AMG330, achieved CR/CRi, and treatment-related severe adverse effects including up to Grade 2 cytokine-releasing syndrome (CRS) were seen in $15(42.9 \%)$ patients. Another CD33-targeted BiTE AMV564 showed reduction of marrow blasts in 12 of $18(66.7 \%)$ patients with RR-AML and up to Grade 2 CRS in one (5.6\%) patient [131]. Currently, two agents of CD123-targeted antibodies, XmAb14045 (also known as SQZ622) and flotetuzumab, have been evaluated in early phase studies of patients with RR-AML. A CD33-directed BiTE XmAb14045 achieved CR/CRi in three of $13(23.1 \%)$ participants who received sufficient doses of the agent and up to Grade 3 CRS in 49 of $63(77.8 \%)$ patients who received any dose in the initial stage of the phase I study [132]. Flotetuzumab is a CD123-/CD3-bispecific DART that has undergone a phase I/II study [133]. Of twenty-seven evaluable patients who received its recommended dose, five $(18.5 \%)$ patients achieved CR/CRi and four $(13.3 \%)$ patients suffered from Grade 3 or more severe CRS. The agent is also being evaluated in combination with an anti-PD-1 antibody, MGA012, in expectation of more potent clinical benefits [134]. A summary of early phase trials is shown in Table 3. 
Table 3. A summary of clinical trials of bispecific antibodies for relapsed/refractory AML (RR-AML). BiTE: bispecific T-cell engager, DART: dual-affinity retargeting molecule, ICI: immune checkpoint inhibitor, CR: complete remission, CRi: CR with incomplete hematologic recovery, CRS: cytokine releasing syndrome.

\begin{tabular}{|c|c|c|c|c|c|c|c|}
\hline Author & Object & Agent(s) & Class & Targets & Phase & \multicolumn{2}{|c|}{ Clinical Outcome } \\
\hline $\begin{array}{c}\text { Ravandi, et al., } \\
2018\end{array}$ & RR-AML & AMG330 & BiTE & $\begin{array}{l}\text { CD33 and } \\
\text { CD3 }\end{array}$ & I & $\begin{array}{l}\text { CR/CRi } \\
\text { CRS }\end{array}$ & $\begin{array}{r}11.4 \%(4 \text { of } 35) \\
42.1 \%(15 \text { of } 35)\end{array}$ \\
\hline $\begin{array}{l}\text { Eissenberg, et al., } \\
2018\end{array}$ & RR-AML & AMV564 & BiTE & $\begin{array}{l}\text { CD33 and } \\
\text { CD3 }\end{array}$ & I & $\begin{array}{l}\text { CR/CRi } \\
\text { CRS }\end{array}$ & $\begin{array}{c}66.7 \%(12 \text { of } 18) \\
5.7 \%(1 \text { of } 18)\end{array}$ \\
\hline $\begin{array}{c}\text { Ravandi, et al., } \\
2018\end{array}$ & RR-AML & XmAb14045 & BiTE & $\begin{array}{l}\text { CD123 and } \\
\text { CD3 }\end{array}$ & I & $\begin{array}{l}\text { CR/CRi } \\
\text { CRS }\end{array}$ & $\begin{array}{r}23.1 \%(3 \text { of } 13) \\
77.9 \%(49 \text { of } 63)\end{array}$ \\
\hline $\begin{array}{l}\text { Uy, et al., } \\
2018\end{array}$ & RR-AML & Flotetuzumab & DART & $\begin{array}{l}\text { CD123 and } \\
\text { CD3 }\end{array}$ & $\mathrm{I} / \mathrm{II}$ & $\begin{array}{c}\text { CR/CRi } \\
\text { Severe CRS }\end{array}$ & $\begin{array}{l}18.5 \%(5 \text { of } 27) \\
13.4 \%(4 \text { of } 30)\end{array}$ \\
\hline $\begin{array}{l}\text { Wei, et al., } \\
2019\end{array}$ & RR-AML & $\begin{array}{l}\text { Flotetuzumab } \\
\text { +MGA012 }\end{array}$ & DART+ ICI & $\begin{array}{l}\text { CD123 and } \\
\text { CD3 } \\
\text { plus PD-1 }\end{array}$ & I & \multicolumn{2}{|c|}{ Not reported } \\
\hline
\end{tabular}

\subsection{Antibody-Drug Conjugate}

CD33 has been recognized for decades as the most popular immune target of AML. An anti-CD33 ADC, GO, showed CR rates of $63 \%$ with 2-year overall survival of $41 \%$ in patients with relapsed/refractory CD33-positive AML [8]. A meta-analysis of five randomized trials in which GO was combined with induction chemotherapy in patients with newly diagnosed AML concluded that this combination significantly reduced relapse within 5 years (hazard ratio (HR) $0.81(0.73-0.90)$ ) and slightly prolonged overall survival (HR 0.90 (0.82-0.98)) without improving response rates (HR 0.91 (0.77-1.07)) [9]. GO monotherapy also showed moderate survival benefit (median survival 4.9 months vs. 3.6 months) without increasing the severe adverse effects compared with best supportive care in the elderly with newly diagnosed AML who were unsuitable for intensive chemotherapy [135]. As mentioned in the earlier sections, novel ADCs targeting CD123 and CLL-1 (e.g., IMGN632 [81] and SL-101 [80] for CD123 and CLT030 [94] for CLL-1) have been shown to have anti-leukemic activity. In the future, they should be evaluated in clinical trials.

\section{Conclusions}

As knowledge of immune inhibitory molecules and leukemic antigens has accumulated, clinical use of IO therapy for AML has come closer to reality. While conventional chemotherapy, with or without SCT, is still pivotal in curative treatment and/or disease control for AML because of its high proliferation intensity, molecular targeted approaches (e.g., GO and FLT3 inhibitors) remain a practical alternative, especially for patients with relapsed/refractory or intolerable AML to intensive treatment. Clinical experience of ICIs in solid tumors has shown that IO therapy brings long-term disease control in at least $10-20 \%$ of the patients with metastatic cancers (more favorable in malignant melanoma, renal cell cancer, and non-small cell lung cancer with high PD-L1 expression, and MSI-high tumors) even after discontinuation of chemotherapy. Furthermore, concomitant use of chemotherapy and/or radiation could enhance the efficacy of IO therapy $[136,137]$, although it has not yet been proven in hematologic malignancies. Long-term follow up of CD19-CAR-T therapy (tisa-cel) for relapsed/refractory B-ALL showed more than 5 years of estimated progression-free survival in approximately $40 \%$ of patients with low disease burden [6]. Selective eradication of cancer stem cells and/or sustained establishment of anti-tumor immunity might be, at least theoretically, able to bring about a true cure for patients with AML who are relapsed/refractory or ineligible for curative treatment. Further advances and clinical applications of IO therapy for AML are awaited. 
Author Contributions: R.T. and S.C. wrote the first draft and all the authors revised the manuscript. All authors have read and agreed to the published version of the manuscript.

Funding: This paper was supported by the National Cancer Research and Development expenses grant.

Institutional Review Board Statement: Not applicable.

Informed Consent Statement: Not applicabl.

Data Availability Statement: Not applicable.

Conflicts of Interest: Y.M. received research funding from Ono and CMIC, and honoraria from Bristol-Myers Squibb, Novartis, Astellas, and Daiichi-Sankyo. The other authors declare no conflict of interest.

\section{References}

1. Specenier, P. Ipilimumab in melanoma. Expert Rev. Anticancer Ther. 2016, 16, 811-826. [CrossRef]

2. Kantarjian, H.M.; Stein, A.; Gökbuget, N.; Fielding, A.K.; Schuh, A.C.; Ribera, J.-M.; Wei, A.; Dombret, H.; Foà, R.; Bassan, R.; et al. Blinatumomab versus Chemotherapy for Advanced Acute Lymphoblastic Leukemia. N. Engl. J. Med. 2017, 376, 836-847. [CrossRef] [PubMed]

3. Goebeler, M.-E.; Knop, S.; Viardot, A.; Kufer, P.; Topp, M.S.; Einsele, H.; Noppeney, R.; Hess, G.; Kallert, S.; Mackensen, A.; et al. Bispecific T-Cell Engager (BiTE) Antibody Construct Blinatumomab for the Treatment of Patients With Relapsed/Refractory Non-Hodgkin Lymphoma: Final Results From a Phase I Study. J. Clin. Oncol. 2016, 34, 1104-1111. [CrossRef]

4. Viardot, A.; Goebeler, M.-E.; Hess, G.; Neumann, S.; Pfreundschuh, M.; Adrian, N.; Zettl, F.; Libicher, M.; Sayehli, C.; Stieglmaier, J.; et al. Phase 2 study of the bispecific T-cell engager (BiTE) antibody blinatumomab in relapsed/refractory diffuse large B-cell lymphoma. Blood 2016, 127, 1410-1416. [CrossRef] [PubMed]

5. Schuster, S.J.; Bishop, M.R.; Tam, C.S.; Waller, E.K.; Borchmann, P.; McGuirk, J.P.; Jäger, U.; Jaglowski, S.; Andreadis, C.; Westin, J.R.; et al. Tisagenlecleucel in Adult Relapsed or Refractory Diffuse Large B-Cell Lymphoma. N. Engl. J. Med. 2019, 380, 45-56. [CrossRef] [PubMed]

6. Park, J.H.; Rivière, I.; Gonen, M.; Wang, X.; Sénéchal, B.; Curran, K.J.; Sauter, C.; Wang, Y.; Santomasso, B.; Mead, E.; et al. Long-Term Follow-up of CD19 CAR Therapy in Acute Lymphoblastic Leukemia. N. Engl. J. Med. 2018, 378, 449-459. [CrossRef] [PubMed]

7. Neelapu, S.S.; Locke, F.L.; Bartlett, N.L.; Lekakis, L.J.; Miklos, D.B.; Jacobson, C.A.; Braunschweig, I.; Oluwole, O.O.; Siddiqi, T.; Lin, Y.; et al. Axicabtagene Ciloleucel CAR T-Cell Therapy in Refractory Large B-Cell Lymphoma. N. Engl. J. Med. 2017, 377, 2531-2544. [CrossRef] [PubMed]

8. Chevallier, P.; Delaunay, J.; Turlure, P.; Pigneux, A.; Hunault, M.; Garand, R.; Guillaume, T.; Avet-Loiseau, H.; Dmytruk, N.; Girault, S.; et al. Long-Term Disease-Free Survival After Gemtuzumab, Intermediate-Dose Cytarabine, and Mitoxantrone in Patients With CD33+Primary Resistant or Relapsed Acute Myeloid Leukemia. J. Clin. Oncol. 2008, 26, 5192-5197. [CrossRef]

9. Hills, R.K.; Castaigne, S.; Appelbaum, F.R.; Delaunay, J.; Petersdorf, S.; Othus, M.; Estey, E.H.; Dombret, H.; Chevret, S.; Ifrah, N.; et al. Addition of gemtuzumab ozogamicin to induction chemotherapy in adult patients with acute myeloid leukaemia: A meta-analysis of individual patient data from randomised controlled trials. Lancet Oncol. 2014, 15, 986-996. [CrossRef]

10. Fife, B.T.; Pauken, K.E. The role of the PD-1 pathway in autoimmunity and peripheral tolerance. Ann. N. Y. Acad. Sci. 2011, 1217, 45-59. [CrossRef]

11. Berger, K.N.; Pu, J.J. PD-1 pathway and its clinical application: A 20 year journey after discovery of the complete human PD-1 gene. Gene 2018, 638, 20-25. [CrossRef]

12. Linsley, P.S.; Brady, W.; Urnes, M.; Grosmaire, L.S.; Damle, N.K.; A Ledbetter, J. CTLA-4 is a second receptor for the B cell activation antigen B7. J. Exp. Med. 1991, 174, 561-569. [CrossRef]

13. Teft, W.A.; Kirchhof, M.G.; Madrenas, J. A MOLECULAR PERSPECTIVE OF CTLA-4 FUNCTION. Annu. Rev. Immunol. 2006, 24, 65-97. [CrossRef]

14. LaBelle, J.L.; Hanke, C.A.; Blazar, B.R.; Truitt, R.L. Negative effect of CTLA-4 on induction of T-cell immunity in vivo to B7-1+, but not B7-2+, murine myelogenous leukemia. Blood J. Am. Soc. Hematol. 2002, 99, 2146-2153. [CrossRef] [PubMed]

15. Yang, H.; Bueso-Ramos, C.; Dinardo, C.D.; Estecio, M.R.; Davanlou, M.; Geng, Q.-R.; Fang, Z.; Nguyen, M.; Pierce, S.; Wei, Y.; et al. Expression of PD-L1, PD-L2, PD-1 and CTLA4 in myelodysplastic syndromes is enhanced by treatment with hypomethylating agents. Leukemia 2014, 28, 1280-1288. [CrossRef] [PubMed]

16. Chen, X.; Liu, S.; Wang, L.; Zhang, W.-G.; Ji, Y.; Ma, X. Clinical significance of B7-H1 (PD-L1) expression in human acute leukemia. Cancer Biol. Ther. 2008, 7, 622-627. [CrossRef] [PubMed]

17. Goltz, D.; Gevensleben, H.; Grünen, S.; Dietrich, J.; Kristiansen, G.; Landsberg, J. PD-L1 (CD274) promoter methylation predicts survival in patients with acute myeloid leukemia. Leukemia 2017, 31, 738-743. [CrossRef] [PubMed] 
18. Goswami, M.; Oetjen, K.; Mulé, B.M.P.; Sheela, M.S.; Wong, H.Y.; Liu, Q.; Calvo, K.R.; Lai, C.E.; Hourigan, C.S. Increased Frequencies of PD-1+ CD8+ Marrow-Infiltrating Lymphocytes Associated with Highly Clonal T-Lymphocyte Expansions in Relapsed and Refractory AML Patients but Not Healthy Adults. Blood 2016, 128, 1644. [CrossRef]

19. Daver, N.; Basu, S.; Garcia-Manero, G.; Cortes, J.E.; Ravandi, F.; Ning, J.; Xiao, L.; Juliana, L.; Kornblau, S.M.; Konopleva, M.; et al. Defining the Immune Checkpoint Landscape in Patients (pts) with Acute Myeloid Leukemia (AML). Blood 2016, $128,2900$. [CrossRef]

20. Tan, J.; Chen, S.; Lu, Y.; Yao, D.; Xu, L.; Zhang, Y.; Yang, L.; Chen, J.; Lai, J.; Yu, Z.; et al. Higher PD-1 expression concurrent with exhausted CD8+ T cells in patients with de novo acute myeloid leukemia. Chin. J. Cancer Res. 2017, 29, 463-470. [CrossRef]

21. Schnorfeil, F.M.; Lichtenegger, F.S.; Emmerig, K.; Schlueter, M.; Neitz, J.S.; Draenert, R.; Hiddemann, W.; Subklewe, M. T cells are functionally not impaired in AML: Increased PD-1 expression is only seen at time of relapse and correlates with a shift towards the memory T cell compartment. J. Hematol. Oncol. 2015, 8, 93. [CrossRef] [PubMed]

22. Monney, L.; Sabatos, C.A.; Gaglia, J.L.; Ryu, A.; Waldner, H.; Chernova, T.; Manning, S.; Greenfield, E.A.; Coyle, A.J.; Sobel, R.A.; et al. Th1-specific cell surface protein Tim-3 regulates macrophage activation and severity of an autoimmune disease. Nat. Cell Biol. 2002, 415, 536-541. [CrossRef]

23. Sánchez-Fueyo, A.; Tian, J.; Picarella, D.; Domenig, C.; Zheng, X.X.; Sabatos, C.A.; Manlongat, N.; Bender, O.; Kamradt, T.; Kuchroo, V.K.; et al. Tim-3 inhibits T helper type 1-mediated auto- and alloimmune responses and promotes immunological tolerance. Nat Immunol. 2003, 4, 1093-1101. [CrossRef] [PubMed]

24. Tomkowicz, B.; Walsh, E.R.; Cotty, A.; Verona, R.; Sabins, N.; Kaplan, F.; Santulli-Marotto, S.; Chin, C.-N.; Mooney, J.L.; Lingham, R.B.; et al. TIM-3 Suppresses Anti-CD3/CD28-Induced TCR Activation and IL-2 Expression through the NFAT Signaling Pathway. PLOS ONE 2015, 10, e0140694. [CrossRef]

25. Gautron, A.-S.; Dominguez-Villar, M.; De Marcken, M.; Hafler, D.A. Enhanced suppressor function of TIM-3+FoxP3+regulatory T cells. Eur. J. Immunol. 2014, 44, 2703-2711. [CrossRef]

26. Wang, F.; He, W.; Zhou, H.; Yuan, J.; Wu, K.; Xu, L.; Chen, Z.K. The Tim-3 ligand galectin-9 negatively regulates CD8+ alloreactive T cell and prolongs survival of skin graft. Cell. Immunol. 2007, 250, 68-74. [CrossRef]

27. Bi, S.; Hong, P.W.; Lee, B.; Baum, L.G. Galectin-9 binding to cell surface protein disulfide isomerase regulates the redox environment to enhance T-cell migration and HIV entry. Proc. Natl. Acad. Sci. USA 2011, 108, 10650-10655. [CrossRef] [PubMed]

28. Gieseke, F.; Kruchen, A.; Tzaribachev, N.; Bentzien, F.; Dominici, M.; Müller, I. Proinflammatory stimuli induce galectin-9 in human mesenchymal stromal cells to suppress T-cell proliferation. Eur. J. Immunol. 2013, 43, 2741-2749. [CrossRef]

29. Golden-Mason, L.; Mcmahan, R.H.; Strong, M.; Reisdorph, R.; Mahaffey, S.; Palmer, B.E.; Cheng, L.; Kulesza, C.; Hirashima, M.; Niki, T.; et al. Galectin-9 Functionally Impairs Natural Killer Cells in Humans and Mice. J. Virol. 2013, 87, 4835-4845. [CrossRef]

30. DeKruyff, R.H.; Bu, X.; Ballesteros, A.; Santiago, C.; Chim, Y.-L.E.; Lee, H.-H.; Karisola, P.; Pichavant, M.; Kaplan, G.G.; Umetsu, D.T.; et al. T Cell/Transmembrane, Ig, and Mucin-3 Allelic Variants Differentially Recognize Phosphatidylserine and Mediate Phagocytosis of Apoptotic Cells. J. Immunol. 2010, 184, 1918-1930. [CrossRef]

31. Chiba, S.; Baghdadi, M.; Akiba, H.; Yoshiyama, H.; Kinoshita, I.; Dosaka-Akita, H.; Fujioka, Y.; Ohba, Y.; Gorman, J.V.; Colgan, J.D.; et al. Tumor-infiltrating DCs suppress nucleic acid-mediated innate immune responses through interactions between the receptor TIM-3 and the alarmin HMGB1. Nat. Immunol. 2012, 13, 832-842. [CrossRef]

32. Huang, Y.-H.; Zhu, C.; Kondo, Y.; Anderson, A.C.; Gandhi, A.; Russell, A.F.; Dougan, S.K.; Petersen, B.-S.; Melum, E.; Pertel, T.; et al. CEACAM1 regulates TIM-3-mediated tolerance and exhaustion. Nat. Cell Biol. 2015, 517, 386-390. [CrossRef] [PubMed]

33. Li, C.; Chen, X.; Yu, X.; Zhu, Y.; Ma, C.; Xia, R.; Ma, J.; Gu, C.; Ye, L.; Wu, D. Tim-3 is highly expressed in T cells in acute myeloid leukemia and associated with clinicopathological prognostic stratification. Int. J. Clin. Exp. Pathol. 2014, 7, $6880-6888$.

34. Kong, Y.; Zhang, J.; Claxton, D.F.; Ehmann, W.C.; Rybka, W.B.; Zhu, L.; Zeng, H.; Schell, T.D.; Zheng, H. PD-1(hi)TIM-3(+) T cells associate with and predict leukemia relapse in AML patients post allogeneic stem cell transplantation. Blood Cancer J. 2015, 5, e330. [CrossRef]

35. Zhou, Q.; Munger, M.E.; Veenstra, R.G.; Weigel, B.J.; Hirashima, M.; Munn, D.H.; Murphy, W.J.; Azuma, M.; Anderson, A.C.; Kuchroo, V.K.; et al. Coexpression of Tim-3 and PD-1 identifies a CD8+ T-cell exhaustion phenotype in mice with disseminated acute myelogenous leukemia. Blood J. Am. Soc. Hematol. 2011, 117, 10.

36. Han, G.; Chen, G.; Shen, B.; Li, Y. Tim-3: An Activation Marker and Activation Limiter of Innate Immune Cells. Front. Immunol. 2013, 4. [CrossRef] [PubMed]

37. Gleason, M.K.; Lenvik, T.R.; McCullar, V.; Felices, M.; O’Brien, M.S.; Cooley, S.A.; Verneris, M.R.; Cichocki, F.; Holman, C.J.; Panoskaltsis-Mortari, A.; et al. Tim-3 is an inducible human natural killer cell receptor that enhances interferon gamma production in response to galectin-9. Blood 2012, 119, 3064-3072. [CrossRef]

38. Folgiero, V.; Cifaldi, L.; Pira, G.L.; Goffredo, B.M.; Vinti, L.; Locatelli, F. TIM-3/Gal-9 interaction induces IFN $\gamma$-dependent IDO1 expression in acute myeloid leukemia blast cells. J. Hematol. Oncol. 2015, 8, 1-5. [CrossRef] [PubMed]

39. Silva, I.G.; Yasinska, I.M.; Sakhnevych, S.S.; Fiedler, W.; Wellbrock, J.; Bardelli, M.; Varani, L.; Hussain, R.; Siligardi, G.; Ceccone, G.; et al. The Tim-3-galectin-9 Secretory Pathway is Involved in the Immune Escape of Human Acute Myeloid Leukemia Cells. EBioMedicine 2017, 22, 44-57. [CrossRef]

40. He, X.; Feng, Z.; Ma, J.; Ling, S.; Cao, Y.; Gurung, B.; Wu, Y.; Katona, B.W.; O’Dwyer, K.P.; Siegel, D.L.; et al. Bispecific and split CAR T cells targeting CD13 and TIM3 eradicate acute myeloid leukemia. Blood 2020, 135, 713-723. [CrossRef] 
41. Baixeras, E.; Huard, B.; Miossec, C.; Jitsukawa, S.; Martin, M.; Hercend, T.; Auffray, C.; Triebel, F.; Piatier-Tonneau, D. Characterization of the lymphocyte activation gene 3-encoded protein. A new ligand for human leukocyte antigen class II antigens. J. Exp. Med. 1992, 176, 327-337. [CrossRef] [PubMed]

42. Workman, C.J.; Wang, Y.; El Kasmi, K.C.; Pardoll, D.M.; Murray, P.J.; Drake, C.G.; Vignali, D.A.A. LAG-3 Regulates Plasmacytoid Dendritic Cell Homeostasis. J. Immunol. 2009, 182, 1885-1891. [CrossRef] [PubMed]

43. Camisaschi, C.; Casati, C.; Rini, F.; Perego, M.; De Filippo, A.; Triebel, F.; Parmiani, G.; Belli, F.; Rivoltini, L.; Castelli, C. LAG-3 Expression Defines a Subset of CD4+CD25highFoxp3+ Regulatory T Cells That Are Expanded at Tumor Sites. J. Immunol. 2010, 184, 6545-6551. [CrossRef] [PubMed]

44. Triebel, F.; Jitsukawa, S.; Baixeras, E.; Roman-Roman, S.; Genevee, C.; Viegas-Pequignot, E.; Hercend, T. LAG-3, a novel lymphocyte activation gene closely related to CD4. J. Exp. Med. 1990, 171, 1393-1405. [CrossRef] [PubMed]

45. Huard, B.; Tournier, M.; Hercend, T.; Triebel, F.; Faure, F. Lymphocyte-activation gene 3/major histocompatibility complex class II interaction modulates the antigenic response of CD4+ T lymphocytes. Eur. J. Immunol. 1994, 24, 3216-3221. [CrossRef] [PubMed]

46. Huard, B.; Prigent, P.; Pagès, F.; Bruniquel, D.; Triebel, F. T cell major histocompatibility complex class II molecules down-regulate CD4+ T cell clone responses following LAG-3 binding. Eur. J. Immunol. 1996, 26, 1180-1186. [CrossRef]

47. Woo, S.-R.; Turnis, M.E.; Goldberg, M.V.; Bankoti, J.; Selby, M.; Nirschl, C.J.; Bettini, M.L.; Gravano, D.M.; Vogel, P.; Liu, C.L.; et al. Immune Inhibitory Molecules LAG-3 and PD-1 Synergistically Regulate T-cell Function to Promote Tumoral Immune Escape. Cancer Res. 2012, 72, 917-927. [CrossRef]

48. Okazaki, T.; Okazaki, I.-M.; Wang, J.; Sugiura, D.; Nakaki, F.; Yoshida, T.; Kato, Y.; Fagarasan, S.; Muramatsu, M.; Eto, T.; et al. PD-1 and LAG-3 inhibitory co-receptors act synergistically to prevent autoimmunity in mice. J. Exp. Med. 2011, 208, 395-407. [CrossRef]

49. Williams, P.; Basu, S.; Garcia-Manero, G.; Hourigan, C.S.; Oetjen, K.A.; Cortes, J.E.; Ravandi, F.; Jabbour, E.J.; Al-Hamal, Z.; Konopleva, M.; et al. The distribution of T-cell subsets and the expression of immune checkpoint receptors and ligands in patients with newly diagnosed and relapsed acute myeloid leukemia. Cancer 2019, 125, 1470-1481. [CrossRef]

50. Wierz, M.; Pierson, S.; Guyonnet, L.; Viry, E.; Lequeux, A.; Oudin, A.; Niclou, S.P.; Ollert, M.; Berchem, G.; Janji, B.; et al. Dual PD1/LAG3 immune checkpoint blockade limits tumor development in a murine model of chronic lymphocytic leukemia. Blood 2018, 131, 1617-1621. [CrossRef]

51. Bristol-Myers Squibb. A Phase 1/2a Dose Escalation and Cohort Expansion Study of the Safety, Tolerability, and Efficacy of Anti-LAG-3 (BMS-986016) in Monoclonal Antibody (BMS-986016) Administered Alone and in Combination With Anti-PD-1 Monoclonal Antibody (Nivolumab, BMS-936558) in Relapsed or Refractory B-Cell Malignancies. clinicaltrials.gov. 2019. Available online: https: / / clinicaltrials.gov/ct2/show / NCT02061761 (accessed on 21 June 2020).

52. Bristol-Myers Squibb. A Phase I/2a Dose Escalation and Cohort Expansion Study of the Safety, Tolerability, and Efficacy of Anti-LAG-3 Monoclonal Antibody (BMS-986016) Administered Alone and in Combination With Anti-PD-1 Monoclonal Antibody (Nivolumab, BMS-936558) in Advanced Solid Tumors. clinicaltrials.gov. 2020. Available online: https://clinicaltrials.gov/ct2 / show / NCT01968109 (accessed on 21 June 2020).

53. Latour, S.; Tanaka, H.; Demeure, C.; Mateo, V.; Rubio, M.; Brown, E.J.; Maliszewski, C.; Lindberg, F.P.; Oldenborg, A.; Ullrich, A.; et al. Bidirectional Negative Regulation of Human T and Dendritic Cells by CD47 and Its Cognate Receptor SignalRegulator Protein- $\alpha$ : Down-Regulation of IL-12 Responsiveness and Inhibition of Dendritic Cell Activation. J. Immunol. 2001, 167, 2547-2554. [CrossRef]

54. Oldenborg, P.-A.; Gresham, H.D.; Lindberg, F.P. Cd47-Signal Regulatory Protein $\alpha$ (Sirp $\alpha$ ) Regulates Fc $\gamma$ and Complement Receptor-Mediated Phagocytosis. J. Exp. Med. 2001, 193, 855-862. [CrossRef] [PubMed]

55. Piccio, L.; Vermi, W.; Boles, K.S.; Fuchs, A.; Strader, C.A.; Facchetti, F.; Cella, M.; Colonna, M. Adhesion of human T cells to antigen-presenting cells through SIRPbeta2-CD47 interaction costimulates T-cell proliferation. Blood 2005, 105, 7. [CrossRef] [PubMed]

56. Jaiswal, S.; Jamieson, C.H.; Pang, W.W.; Park, C.Y.; Chao, M.P.; Majeti, R.; Traver, D.; Van Rooijen, N.; Weissman, I.L. CD47 Is Upregulated on Circulating Hematopoietic Stem Cells and Leukemia Cells to Avoid Phagocytosis. Cell 2009, 138, 271-285. [CrossRef]

57. Majeti, R.; Chao, M.P.; Alizadeh, A.A.; Pang, W.W.; Jaiswal, S.; Gibbs, K.D.; Van Rooijen, N.; Weissman, I.L. CD47 Is an Adverse Prognostic Factor and Therapeutic Antibody Target on Human Acute Myeloid Leukemia Stem Cells. Cell 2009, 138, $286-299$. [CrossRef]

58. Petrova, P.S.; Viller, N.N.; Wong, M.; Pang, X.; Lin, G.H.Y.; Dodge, K.; Chai, V.; Chen, H.; Lee, V.; House, V.; et al. TTI-621 $(\mathrm{SIRP} \alpha \mathrm{Fc})$ : A CD47-Blocking Innate Immune Checkpoint Inhibitor with Broad Antitumor Activity and Minimal Erythrocyte Binding. Clin. Cancer Res. 2017, 23, 1068-1079. [CrossRef] [PubMed]

59. Advani, R.; Flinn, I.; Popplewell, L.; Forero, A.; Bartlett, N.L.; Ghosh, N.; Kline, J.; Roschewski, M.; LaCasce, A.; Collins, G.P.; et al. CD47 Blockade by Hu5F9-G4 and Rituximab in Non-Hodgkin's Lymphoma. N. Engl. J. Med. 2018, 379, 1711-1721. [CrossRef]

60. Brierley, C.; Staves, J.; Roberts, C.; Johnson, H.; Vyas, P.; Goodnough, L.; Murphy, M. The effects of monoclonal anti-CD47 on RBCs, compatibility testing, and transfusion requirements in refractory acute myeloid leukemia. Transfusion 2019, 59, $2248-2254$. [CrossRef]

61. Hobo, W.; Hutten, T.J.A.; Schaap, N.P.M.; Dolstra, H. Immune checkpoint molecules in acute myeloid leukaemia: Managing the double-edged sword. Br. J. Haematol. 2018, 181, 38-53. [CrossRef] 
62. Krieg, C.; Han, P.; Stone, R.; Goularte, O.D.; Kaye, J. Functional Analysis of B and T Lymphocyte Attenuator Engagement on CD4+ and CD8+ T Cells. J. Immunol. 2005, 175, 6420-6427. [CrossRef]

63. Wright, G.J.; Puklavec, M.J.; Willis, A.C.; Hoek, R.M.; Sedgwick, J.D.; Brown, M.H.; Barclay, A. Lymphoid/Neuronal Cell Surface OX2 Glycoprotein Recognizes a Novel Receptor on Macrophages Implicated in the Control of Their Function. Immunity 2000, 13, 233-242. [CrossRef]

64. Chen, J.-X.; Mei, L.-P.; Chen, B.-G.; Wang, D.-L.; Luo, W.-D.; Luo, L.-F.; Lu, R.; Zheng, R.; Zhang, L. Over-expression of CD200 predicts poor prognosis in MDS. Leuk. Res. 2017, 56, 1-6. [CrossRef] [PubMed]

65. Lasaro, M.; Sazanovich, M.; Giles-Davis, W.; Mrass, P.; Bunte, R.M.; Sewell, D.; Hussain, S.F.; Fu, Y.-X.; Weninger, W.; Paterson, Y.; et al. Active Immunotherapy Combined With Blockade of a Coinhibitory Pathway Achieves Regression of Large Tumor Masses in Cancer-prone Mice. Mol. Ther. 2011, 19, 1727-1736. [CrossRef] [PubMed]

66. Coles, S.J.; Wang, E.C.Y.; Man, S.; Hills, R.K.; Burnett, A.K.; Tonks, A.; Darley, R.L. CD200 expression suppresses natural killer cell function and directly inhibits patient anti-tumor response in acute myeloid leukemia. Leukemia 2011, 25, 792-799. [CrossRef]

67. Prasad, D.V.R.; Nguyen, T.; Li, Z.; Yang, Y.; Duong, J.; Wang, Y.; Dong, C. Murine B7-H3 is a negative regulator of T cells. J. Immunol. 2004, 173, 2500-2506. [CrossRef]

68. Picarda, E.; Ohaegbulam, K.C.; Zang, X. Molecular Pathways: Targeting B7-H3 (CD276) for Human Cancer Immunotherapy. Clin. Cancer Res. 2016, 22, 3425-3431. [CrossRef]

69. Lichtman, E.; Du, H.; Savoldo, B.; Ferrone, S.; Li, G.; Su, L.; Dotti, G. Pre-Clinical Evaluation of B7-H3-Specific Chimeric Antigen Receptor T-Cells for the Treatment of Acute Myeloid Leukemia. Blood 2018, 132, 701. [CrossRef]

70. Muñoz, L.; Nomdedéu, J.F.; López, O.; Carnicer, M.J.; Bellido, M.; Aventín, A.; Brunet, S.; Sierra, J. Interleukin-3 receptor alpha chain (CD123) is widely expressed in hematologic malignancies. Haematologica 2001, 86, 1261-1269.

71. Testa, U.; Pelosi, E.; Frankel, A. CD 123 is a membrane biomarker and a therapeutic target in hematologic malignancies. Biomark. Res. 2014, 2, 4. [CrossRef]

72. Ehninger, G.; on behalf of the Study Alliance Leukemia; Kramer, M.; Rollig, C.; Thiede, C.; Bornhauser, M.; Von Bonin, M.; Wermke, M.; Feldmann, A.; Bachmann, M.F.; et al. Distribution and levels of cell surface expression of CD33 and CD123 in acute myeloid leukemia. Blood Cancer J. 2014, 4, e218. [CrossRef] [PubMed]

73. Vergez, F.; Green, A.S.; Tamburini, J.; Sarry, J.-E.; Gaillard, B.; Cornillet-Lefebvre, P.; Pannetier, M.; Neyret, A.; Chapuis, N.; Ifrah, N.; et al. High levels of CD34+CD38low / -CD123+ blasts are predictive of an adverse outcome in acute myeloid leukemia: A Groupe Ouest-Est des Leucémies Aiguës et Maladies du Sang (GOELAMS) study. Haematologica 2011, 96, 1792-1798. [CrossRef]

74. Angelini, D.F.; Ottone, T.; Guerrera, G.; Lavorgna, S.; Cittadini, M.; Buccisano, F.; De Bardi, M.; Gargano, F.; Maurillo, L.; Divona, M.; et al. A Leukemia-Associated CD34/CD123/CD25/CD99+ Immunophenotype Identifies FLT3-Mutated Clones in Acute Myeloid Leukemia. Clin. Cancer Res. 2015, 21, 3977-3985. [CrossRef]

75. Yan, B.; Chen, Q.; Shimada, K.; Tang, M.; Li, H.; Gurumurthy, A.; Khoury, J.D.; Xu, B.; Huang, S.; Qiu, Y. Histone deacetylase inhibitor targets CD123/CD47-positive cells and reverse chemoresistance phenotype in acute myeloid leukemia. Leukemia 2019, 33, 931-944. [CrossRef]

76. Al-Hussaini, M.; Rettig, M.P.; Ritchey, J.K.; Karpova, D.; Uy, G.L.; Eissenberg, L.G.; Gao, F.; Eades, W.C.; Bonvini, E.; Chichili, G.R.; et al. Targeting CD123 in acute myeloid leukemia using a T-cell-directed dual-affinity retargeting platform. Blood 2016, 127, 122-131. [CrossRef] [PubMed]

77. Pizzitola, I.; Anjosafonso, F.; Rouaultpierre, K.; Lassailly, F.; Tettamanti, S.; Spinelli, O.; Biondi, A.; Biagi, E.; Bonnet, D. Chimeric antigen receptors against CD33/CD123 antigens efficiently target primary acute myeloid leukemia cells in vivo. Leukemia 2014, 28, 1596-1605. [CrossRef] [PubMed]

78. Bonifant, C.L.; Szoor, A.; Torres, D.; Joseph, N.; Velasquez, M.P.; Iwahori, K.; Gaikwad, A.; Nguyen, P.; Arber, C.; Song, X.-T.; et al CD123-Engager T Cells as a Novel Immunotherapeutic for Acute Myeloid Leukemia. Mol. Ther. 2016, 24, 1615-1626. [CrossRef]

79. Xie, L.H.; Biondo, M.; Busfield, S.J.; Arruda, A.; Yang, X.; Vairo, G.; Minden, M.D. CD123 target validation and preclinical evaluation of ADCC activity of anti-CD123 antibody CSL362 in combination with NKs from AML patients in remission. Blood Cancer J. 2017, 7, e567. [CrossRef] [PubMed]

80. Han, L.; Jorgensen, J.L.; Brooks, C.; Shi, C.; Zhang, Q.; González, G.M.N.; Cavazos, A.; Pan, R.; Mu, H.; Wang, S.A.; et al. Antileukemia Efficacy and Mechanisms of Action of SL-101, a Novel Anti-CD123 Antibody Conjugate, in Acute Myeloid Leukemia. Clin. Cancer Res. 2017, 23, 3385-3395. [CrossRef]

81. Kovtun, Y.; Jones, G.E.; Adams, S.; Harvey, L.; Audette, C.A.; Wilhelm, A.; Bai, C.; Rui, L.; Laleau, R.; Liu, F.; et al. A CD123targeting antibody-drug conjugate, IMGN632, designed to eradicate AML while sparing normal bone marrow cells. Blood Adv. 2018, 2, 848-858. [CrossRef] [PubMed]

82. Taussig, D.C. Hematopoietic stem cells express multiple myeloid markers: Implications for the origin and targeted therapy of acute myeloid leukemia. Blood 2005, 106, 4086-4092. [CrossRef] [PubMed]

83. De Propris, M.S.; Raponi, S.; Diverio, D.; Milani, M.L.; Meloni, G.; Falini, B.; Foa, R.; Guarini, A. High CD33 expression levels in acute myeloid leukemia cells carrying the nucleophosmin (NPM1) mutation. Haematologica 2011, 96, 1548-1551. [CrossRef]

84. Khan, N.; on behalf of the UK NCRI-AML Study Group; Hills, R.K.; Virgo, P.; Couzens, S.; Clark, N.; Gilkes, A.; Richardson, P.; Knapper, S.; Grimwade, D.; et al. Expression of CD33 is a predictive factor for effect of gemtuzumab ozogamicin at different doses in adult acute myeloid leukaemia. Leukemia 2017, 31, 1059-1068. [CrossRef] [PubMed] 
85. Olombel, G.; Guerin, E.; Guy, J.; Perrot, J.-Y.; Dumezy, F.; De Labarthe, A.; Bastie, J.-N.; Legrand, O.; Raffoux, E.; Plesa, A.; et al. The level of blast CD33 expression positively impacts the effect of gemtuzumab ozogamicin in patients with acute myeloid leukemia. Blood 2016, 127, 2157-2160. [CrossRef] [PubMed]

86. Pollard, J.A.; Alonzo, T.A.; Loken, M.; Gerbing, R.B.; Ho, P.A.; Bernstein, I.D.; Raimondi, S.C.; Hirsch, B.; Franklin, J.; Walter, R.B.; et al. Correlation of CD33 expression level with disease characteristics and response to gemtuzumab ozogamicin containing chemotherapy in childhood AML. Blood 2012, 119, 3705-3711. [CrossRef]

87. Friedrich, M.; Henn, A.; Raum, T.; Bajtus, M.; Matthes, K.; Hendrich, L.; Wahl, J.; Hoffmann, P.; Kischel, R.; Kvesic, M.; et al. Preclinical Characterization of AMG 330, a CD3/CD33-Bispecific T-Cell-Engaging Antibody with Potential for Treatment of Acute Myelogenous Leukemia. Mol. Cancer Ther. 2014, 13, 1549-1557. [CrossRef]

88. Herrmann, M.; Krupka, C.; Deiser, K.; Brauchle, B.; Marcinek, A.; Wagner, A.O.; Rataj, F.; Mocikat, R.; Metzeler, K.H.; Spiekermann, K.; et al. Bifunctional PD- $1 \times \alpha \mathrm{CD} 3 \times \alpha \mathrm{CD} 33$ fusion protein reverses adaptive immune escape in acute myeloid leukemia. Blood 2018, 132, 2484-2494. [CrossRef]

89. Neumann, K.; Castineiras-Vilarino, M.; Höckendorf, U.; Hannesschläger, N.; Lemeer, S.; Kupka, D.; Meyermann, S.; Lech, M.; Anders, H.-J.; Kuster, B.; et al. Clec12a Is an Inhibitory Receptor for Uric Acid Crystals that Regulates Inflammation in Response to Cell Death. Immunity 2014, 40, 389-399. [CrossRef]

90. Redelinghuys, P.; Whitehead, L.; Augello, A.; Drummond, R.A.; Levesque, J.-M.; Vautier, S.; Reid, D.M.; Kerscher, B.; Taylor, J.A.; Nigrovic, P.A.; et al. MICL controls inflammation in rheumatoid arthritis. Ann. Rheum. Dis. 2015, 75, 1386-1391. [CrossRef]

91. Van Rhenen, A.; Van Dongen, G.A.M.S.; Kelder, A.; Rombouts, E.J.; Feller, N.; Moshaver, B.; Walsum, M.S.-V.; Zweegman, S.; Ossenkoppele, G.J.; Schuurhuis, G.J. The novel AML stem cell-associated antigen CLL-1 aids in discrimination between normal and leukemic stem cells. Blood 2007, 110, 2659-2666. [CrossRef]

92. Hutten, T.J.A.; Thordardottir, S.; Fredrix, H.; Janssen, L.; Woestenenk, R.; Tel, J.; Joosten, B.; Cambi, A.; Heemskerk, M.H.M.; Franssen, G.M.; et al. CLEC12A-Mediated Antigen Uptake and Cross-Presentation by Human Dendritic Cell Subsets Efficiently Boost Tumor-Reactive T Cell Responses. J. Immunol. 2016, 197, 2715-2725. [CrossRef]

93. Zheng, B.; Yu, S.-F.; Del Rosario, G.; Leong, S.R.; Lee, G.Y.; Vij, R.; Chiu, C.P.; Liang, W.-C.; Wu, Y.; Chalouni, C.; et al. An Anti-CLL-1 Antibody-Drug Conjugate for the Treatment of Acute Myeloid Leukemia. Clin. Cancer Res. 2019, 25, 1358-1368. [CrossRef]

94. Jiang, Y.-P.; Liu, B.Y.; Zheng, Q.; Panuganti, S.; Chen, R.; Zhu, J.; Mishra, M.; Huang, J.; Dao-Pick, T.; Roy, S.; et al. CLT030, a leukemic stem cell-targeting CLL1 antibody-drug conjugate for treatment of acute myeloid leukemia. Blood Adv. 2018, 2, 1738-1749. [CrossRef]

95. Ma, H.; Padmanabhan, I.S.; Parmar, S.; Gong, Y. Targeting CLL-1 for acute myeloid leukemia therapy. J. Hematol. Oncol. 2019, 12, 1-11. [CrossRef]

96. Zhao, X.; Singh, S.; Pardoux, C.; Zhao, J.; Hsi, E.D.; Abo, A.; Korver, W. Targeting C-type lectin-like molecule-1 for antibodymediated immunotherapy in acute myeloid leukemia. Haematologica 2009, 95, 71-78. [CrossRef]

97. Leong, S.R.; Sukumaran, S.; Hristopoulos, M.; Totpal, K.; Stainton, S.; Lu, E.; Wong, A.; Tam, L.; Newman, R.; Vuillemenot, B.R.; et al. An anti-CD3/anti-CLL-1 bispecific antibody for the treatment of acute myeloid leukemia. Blood 2017, 129, 609-618. [CrossRef]

98. Lu, H.; Zhou, Q.; Deshmukh, V.; Phull, H.; Ma, J.; Tardif, V.; Naik, R.R.; Bouvard, C.; Zhang, Y.; Choi, S.; et al. Targeting Human C-Type Lectin-like Molecule-1 (CLL1) with a Bispecific Antibody for Immunotherapy of Acute Myeloid Leukemia. Angew. Chem. Int. Ed. 2014, 53, 9841-9845. [CrossRef]

99. Van Loo, P.F.; Doornbos, R.; Dolstra, H.; Shamsili, S.; Bakker, L. Preclinical Evaluation of MCLA117, a CLEC12AxCD3 Bispecific Antibody Efficiently Targeting a Novel Leukemic Stem Cell Associated Antigen in AML. Blood 2015, 126, 325. [CrossRef]

100. Tashiro, H.; Sauer, T.; Shum, T.; Parikh, K.; Mamonkin, M.; Omer, B.; Rouce, R.H.; Lulla, P.; Rooney, C.M.; Gottschalk, S.; et al Treatment of Acute Myeloid Leukemia with T Cells Expressing Chimeric Antigen Receptors Directed to C-type Lectin-like Molecule 1. Mol. Ther. 2017, 25, 2202-2213. [CrossRef]

101. Laborda, E.; Mazagova, M.; Shao, S.; Wang, X.; Quirino, H.; Woods, A.K.; Hampton, E.N.; Rodgers, D.T.; Kim, C.H.; Schultz, P.G.; et al. Development of A Chimeric Antigen Receptor Targeting C-Type Lectin-Like Molecule-1 for Human Acute Myeloid Leukemia. Int. J. Mol. Sci. 2017, 18, 2259. [CrossRef]

102. Kenderian, S.S.; Ruella, M.; Shestova, O.; Klichinsky, M.; Kim, M.Y.; Soderquist, C.; Bagg, A.; Singh, R.; Richardson, C.; Young, R.M.; et al. Leukemia Stem Cells Are Characterized By CLEC12A Expression and Chemotherapy Refractoriness That Can be Overcome By Targeting with Chimeric Antigen Receptor T Cells. Blood 2016, 128, 766. [CrossRef]

103. Wang, J.; Chen, S.; Xiao, W.; Li, W.; Wang, L.; Yang, S.; Wang, W.; Xu, L.; Liao, S.; Liu, W.; et al. CAR-T cells targeting CLL-1 as an approach to treat acute myeloid leukemia. J. Hematol. Oncol. 2018, 11, 7. [CrossRef]

104. De Togni, E.; Kim, M.Y.; Cooper, M.L.; Ritchey, J.; O’Neal, J.; Niswonger, J.; DiPersio, J.F. Chimeric Antigen Receptor T Cells Specific for CLL-1 for Treatment of Acute Myeloid Leukemia. Blood 2018, 132, 2205. [CrossRef]

105. Arvindam, U.S.; Van Hauten, P.; Hallstrom, C.; Vallera, D.A.; Dolstra, H.; Miller, J.S.; Felices, M. CD16-IL15-CLEC12A Trispecific Killer Engager (TriKE) Drives NK Cell Expansion, Activation, and Antigen Specific Killing of Cancer Stem Cells in Acute Myeloid Leukemia. Blood 2018, 132, 1454. [CrossRef]

106. Gao, X.; Lin, J.; Gao, L.; Deng, A.; Lu, X.; Li, Y.; Wang, L.; Yu, L. High Expression of c-kit mRNA Predicts Unfavorable Outcome in Adult Patients with $\mathrm{t}(8 ; 21)$ Acute Myeloid Leukemia. PLoS ONE 2015, 10, e124241. [CrossRef] 
107. Myburgh, R.; Kiefer, J.D.; Russkamp, N.F.; Magnani, C.F.; Nuñez, N.; Simonis, A.; Pfister, S.; Wilk, C.M.; McHugh, D.; Friemel, J.; et al. Anti-human CD117 CAR T-cells efficiently eliminate healthy and malignant CD117-expressing hematopoietic cells. Leukemia 2020, 34, 2688-2703. [CrossRef]

108. Kikushige, Y.; Yoshimoto, G.; Miyamoto, T.; Iino, T.; Mori, Y.; Iwasaki, H.; Niiro, H.; Takenaka, K.; Nagafuji, K.; Harada, M.; et al. Human Flt3 Is Expressed at the Hematopoietic Stem Cell and the Granulocyte/Macrophage Progenitor Stages to Maintain Cell Survival. J. Immunol. 2008, 180, 7358-7367. [CrossRef]

109. Stirewalt, D.L.; Radich, J.P. The role of FLT3 in haematopoietic malignancies. Nat. Rev. Cancer 2003, 3, 650-665. [CrossRef]

110. Perl, A.E.; Martinelli, G.; Cortes, J.E.; Neubauer, A.; Berman, E.; Paolini, S.; Montesinos, P.; Baer, M.R.; Larson, R.A.; Ustun, C.; et al. Gilteritinib or Chemotherapy for Relapsed or Refractory FLT3-Mutated AML. N. Engl. J. Med. 2019, 381, 1728-1740. [CrossRef]

111. Stone, R.M.; Mandrekar, S.J.; Sanford, B.L.; Laumann, K.; Geyer, S.; Bloomfield, C.D.; Thiede, C.; Prior, T.W.; Döhner, K.; Marcucci, G.; et al. Midostaurin plus Chemotherapy for Acute Myeloid Leukemia with a FLT3 Mutation. N. Engl. J. Med. 2017, 377, 454-464. [CrossRef]

112. Cortes, J.E.; Khaled, S.; Martinelli, G.; Perl, A.; Ganguly, S.; Russell, N.; Krämer, A.; Dombret, H.; Hogge, D.; Jonas, B.; et al. Quizartinib versus salvage chemotherapy in relapsed or refractory FLT3-ITD acute myeloid leukaemia (QuANTUM-R): A multicentre, randomised, controlled, open-label, phase 3 trial. Lancet Oncol. 2019, 20, 984-997. [CrossRef]

113. Jetani, H.; Garcia-Cadenas, I.; Nerreter, T.; Thomas, S.; Rydzek, J.; Meijide, J.B.; Bonig, H.; Herr, W.; Sierra, J.; Einsele, H.; et al. CAR T-cells targeting FLT3 have potent activity against FLT3-ITD+ AML and act synergistically with the FLT3-inhibitor crenolanib. Leukemia 2018, 32, 1168-1179. [CrossRef]

114. Seitz, C.M.; Kieble, C.V.; Illi, C.C.; Reiter, C.S.; Grote, M.S.; Mittelstaet, J.; Lock, M.D.; Kaiser, A.; Schleicher, S.; Handgretinger, R.; et al. Combinatorial Targeting of Multiple Shared Antigens By Adapter-CAR-T Cells (aCAR-Ts) Allows Target Cell Discrimination and Specific Lysis Based on Differential Expression Profiles. Blood 2018, 132, 4543. [CrossRef]

115. Daver, N.; Basu, S.; Garcia-Manero, G.; Cortes, J.E.; Ravandi, F.; Jabbour, E.J.; Hendrickson, R.S.; Pierce, B.S.; Ning, J.; Konopleva, M.; et al. Phase IB/II Study of Nivolumab in Combination with Azacytidine (AZA) in Patients (pts) with Relapsed Acute Myeloid Leukemia (AML). Blood 2016, 128, 763. [CrossRef]

116. Daver, N.G.; Garcia-Manero, G.; Basu, S.; Cortes, J.E.; Ravandi, F.; Kadia, T.M.; Konopleva, M.Y.; Jabbour, E.J.; Dinardo, C.D.; Assi, R.; et al. Safety, Efficacy, and Biomarkers of Response to Azacitidine (AZA) with Nivolumab (Nivo) and AZA with Nivo and Ipilimumab (Ipi) in Relapsed/Refractory Acute Myeloid Leukemia: A Non-Randomized, Phase 2 Study. Blood 2018, $132,906$. [CrossRef]

117. Ravandi, F.; Assi, R.; Daver, N.; Benton, C.B.; Kadia, T.; Thompson, P.; Borthakur, G.; Alvarado, Y.; Jabbour, E.J.; Konopleva, M.; et al. Idarubicin, cytarabine, and nivolumab in patients with newly diagnosed acute myeloid leukaemia or high-risk myelodysplastic syndrome: A single-arm, phase 2 study. Lancet Haematol. 2019, 6, e480-e488. [CrossRef]

118. Lindblad, E.K.; Thompson, J.; Gui, G.; Valdez, J.; Worthy, T.; Tekleab, H.; Hughes, T.; Goswami, M.; Oetjen, K.; Kim, N.-Y.; et al. Pembrolizumab and Decitabine for Refractory or Relapsed Acute Myeloid Leukemia. Blood 2018, 132, 1437. [CrossRef]

119. Davids, M.S.; Kim, H.T.; Bachireddy, P.; Costello, C.; Liguori, R.; Savell, A.; Lukez, A.P.; Avigan, D.; Chen, Y.-B.; McSweeney, P.; et al. Ipilimumab for Patients with Relapse after Allogeneic Transplantation. N. Engl. J. Med. 2016, 375, 143-153. [CrossRef] [PubMed]

120. Bashey, A.; Medina, B.; Corringham, S.; Pasek, M.; Carrier, E.; Vrooman, L.; Lowy, I.; Solomon, S.R.; Morris, L.E.; Holland, H.K.; et al. CTLA4 blockade with ipilimumab to treat relapse of malignancy after allogeneic hematopoietic cell transplantation. Blood 2009, 113, 1581-1588. [CrossRef] [PubMed]

121. Zeidan, A.M.; Knaus, H.A.; Robinson, T.M.; Towlerton, A.M.; Warren, E.H.; Zeidner, J.F.; Blackford, A.L.; Duffield, A.S.; Rizzieri, D.; Frattini, M.G.; et al. A Multi-center Phase I Trial of Ipilimumab in Patients with Myelodysplastic Syndromes following Hypomethylating Agent Failure. Clin. Cancer Res. 2018, 24, 3519-3527. [CrossRef]

122. Borate, U.; Esteve, J.; Porkka, K.; Knapper, S.; Vey, N.; Scholl, S.; Garcia-Manero, G.; Wermke, M.; Janssen, J.; Traer, E.; et al. Phase Ib Study of the Anti-TIM-3 Antibody MBG453 in Combination with Decitabine in Patients with High-Risk Myelodysplastic Syndrome (MDS) and Acute Myeloid Leukemia (AML). Blood 2019, 134, 570. [CrossRef]

123. Ritchie, D.S.; Neeson, P.J.; Khot, A.; Peinert, S.; Tai, T.; Tainton, K.; Chen, K.; Shin, M.; Wall, D.M.; Hönemann, D.; et al. Persistence and Efficacy of Second Generation CAR T Cell Against the LeY Antigen in Acute Myeloid Leukemia. Mol. Ther. 2013, 21, 2122-2129. [CrossRef]

124. Wang, Q.-S.; Wang, Y.; Lv, H.-Y.; Han, Q.-W.; Fan, H.; Guo, B.; Wang, L.-L.; Han, W.-D. Treatment of CD33-directed Chimeric Antigen Receptor-modified T Cells in One Patient with Relapsed and Refractory Acute Myeloid Leukemia. Mol. Ther. 2015, 23, 184-191. [CrossRef]

125. Tang, X.; Yang, L.; Li, Z.; Nalin, A.P.; Dai, H.; Xu, T.; Yin, J.; You, F.; Zhu, M.; Shen, W.; et al. First-in-man clinical trial of CAR NK-92 cells: Safety test of CD33-CAR NK-92 cells in patients with relapsed and refractory acute myeloid leukemia. Am. J. Cancer Res. 2018, 8, 1899.

126. Suh, H.C.; Pohl, K.A.; Termini, C.; Kan, J.; Timmerman, J.M.; Slamon, D.J.; Chute, J.P. Bioengineered Autologous Dendritic Cells Enhance CAR T Cell Cytotoxicity By Providing Cytokine Stimulation and Intratumoral Dendritic Cells. Blood 2018, $132,3693$. [CrossRef] 
127. Liu, F.; Cao, Y.; Pinz, K.; Ma, Y.; Wada, M.; Chen, K.; Ma, G.; Shen, J.; Tse, C.O.; Su, Y.; et al. First-in-Human CLL1-CD33 Compound CAR T Cell Therapy Induces Complete Remission in Patients with Refractory Acute Myeloid Leukemia: Update on Phase 1 Clinical Trial. Blood 2018, 132, 901. [CrossRef]

128. Sallman, D.; Kerre, T.; Poire, X.; Havelange, V.; Lewalle, P.; Davila, M.L.; Wang, E.S.; Dekker, D.; Snykers, S.; Sotiropoulou, P.A.; et al. Remissions in Relapse/Refractory Acute Myeloid Leukemia Patients Following Treatment with NKG2D CAR-T Therapy without a Prior Preconditioning Chemotherapy. Blood 2018, 132, 902. [CrossRef]

129. Velasquez, M.P.; Bonifant, C.L.; Gottschalk, S. Redirecting T cells to hematological malignancies with bispecific antibodies. Blood 2018, 131, 30-38. [CrossRef]

130. Ravandi, F.; Stein, A.S.; Kantarjian, H.M.; Walter, P.M.R.B.; Paschka, P.; Jongen-Lavrencic, M.; Ossenkoppele, G.J.; Yang, Z.; Mehta, B.; Subklewe, M. A Phase 1 First-in-Human Study of AMG 330, an Anti-CD33 Bispecific T-Cell Engager (BiTE®) Antibody Construct, in Relapsed/Refractory Acute Myeloid Leukemia (R/R AML). Blood 2018, 132, 25. [CrossRef]

131. Westervelt, P.; Roboz, G.J.; Cortes, J.E.; Kantarjian, H.M.; Lee, S.; Rettig, M.P.; Han, T.H.; Guenot, J.; Feldman, E.J.; DiPersio, J.F. Phase 1 First-in-Human Trial of AMV564, a Bivalent Bispecific (2x2) CD33/CD3 T-Cell Engager, in Patients with Relapsed/Refractory Acute Myeloid Leukemia (AML). Blood 2018, 132, 1455. [CrossRef]

132. Ravandi, F.; Bashey, A.; Foran, J.M.; Stock, W.; Mawad, R.; Blum, W.; Saville, M.W.; Johnson, B.C.M.; Vanasse, K.G.J.; Ly, T.; et al. Complete Responses in Relapsed/Refractory Acute Myeloid Leukemia (AML) Patients on a Weekly Dosing Schedule of XmAb14045, a CD123 x CD3 T Cell-Engaging Bispecific Antibody: Initial Results of a Phase 1 Study. Blood 2018, $132,763$. [CrossRef]

133. Uy, G.L.; Rettig, M.P.; Vey, N.; Godwin, J.; Foster, M.C.; Rizzieri, D.A.; Arellano, M.L.; Topp, M.S.; Huls, G.; Jongen-Lavrencic, M.; et al. Phase 1 Cohort Expansion of Flotetuzumab, a CD123 $\times$ CD3 Bispecific Dart@Protein in Patients with Relapsed/Refractory Acute Myeloid Leukemia (AML). Blood 2018, 132, 764. [CrossRef]

134. Wei, A.H.; Fong, C.Y.; Montesinos, P.; Calbacho, M.; Gil, J.S.; De Oteyza, J.P.; Rowe, J.M.; Wolach, O.; Ofran, Y.; Moshe, Y.; et al. A Phase 1 Study of Flotetuzumab, a CD123 x CD3 DART®Protein, Combined with MGA012, an Anti-PD-1 Antibody, in Patients with Relapsed or Refractory Acute Myeloid Leukemia. Blood 2019, 134, 2662. [CrossRef]

135. Amadori, S.; Suciu, S.; Selleslag, D.; Aversa, F.; Gaidano, G.; Musso, M.; Annino, L.; Venditti, A.; Voso, M.T.; Mazzone, C.; et al Gemtuzumab Ozogamicin Versus Best Supportive Care in Older Patients With Newly Diagnosed Acute Myeloid Leukemia Unsuitable for Intensive Chemotherapy: Results of the Randomized Phase III EORTC-GIMEMA AML-19 Trial. J. Clin. Oncol. 2016, 34, 972-979. [CrossRef] [PubMed]

136. Heinhuis, K.; Ros, W.; Kok, M.; Steeghs, N.; Beijnen, J.; Schellens, J. Enhancing antitumor response by combining immune checkpoint inhibitors with chemotherapy in solid tumors. Ann. Oncol. 2019, 30, 219-235. [CrossRef] [PubMed]

137. Dagoglu, N.; Karaman, S.; Caglar, H.B.; Oral, E.N. Abscopal Effect of Radiotherapy in the Immunotherapy Era: Systematic Review of Reported Cases. Cureus 2019, 11. [CrossRef] 